Ross, P.-S. et White, J.D.L. (2006) Debris jets in continental phreatomagmatic volcanoes: a field study of their subterranean deposits in the Coombs Hills vent complex, Antarctica. Journal of Volcanology and Geothermal Research 149: $62-84$

\title{
Debris jets in continental phreatomagmatic volcanoes: a field study of their subterranean deposits in the Coombs Hills vent complex, Antarctica
}

\author{
Pierre-Simon Ross* and James D.L. White \\ Department of Geology, University of Otago, PO Box 56, Dunedin, New Zealand \\ * Corresponding author \\ Email addresses: p_s_ross@ @otmail.com (P.-S. Ross); james.white@ stonebow.otago.ac.nz (J.D.L. White)
}

\begin{abstract}
The Ferrar large igneous province of Antarctica contains significant mafic volcaniclastic deposits, some of which are interpreted to fill large vent complexes. Such a complex was re-examined at Coombs Hills to map individual steepsided cross-cutting bodies in detail, and we found several contrasting types, two of which are interpreted to have filled subterranean passageways forcefully opened from below into existing, non-consolidated debris. These transient conduits were opened because of the propagation of debris jets - upward-moving streams of volcaniclastic debris, steam, magmatic gases +/- liquid water droplets - following explosive magma-aquifer interaction. Some debris jets probably remained wholly subterranean, whereas other made it to the surface, but the studied outcrops do not allow us to differentiate between these cases. The pipes filled with country rock-rich lapilli-tuff or tuff-breccia are interpreted to have formed following phreatomagmatic explosions occurring near the walls or floor of the vent complex, causing fragmentation of both magma and abundant country rock material. In contrast, some of the cross-cutting zones filled with basalt-rich tuff-breccia or lapilli-tuff could have been generated following explosions taking place within preexisting basalt-bearing debris, well away from the complex walls or floor. We infer that once focused jets were formed, they did not incorporate significant amounts of existing Mawson debris while travelling through them; instead, incorporation of fragments from the granular host took place near explosion sites. Other basalt-rich tuff-breccia zones, accompanied by domains of in situ peperite and coherent basalt pods, are inferred to have originated by less violent processes.
\end{abstract}

Keywords: debris jets; Coombs Hills; basaltic volcaniclastic rocks; vent complex; Ferrar

\section{Introduction}

Mafic volcaniclastic deposits are increasingly recognized as a significant component of many large igneous provinces (see Ross et al., 2005 for a review of these deposits worldwide). One topic of current interest in this context is the development of huge vent complexes filled with mostly coarse, non-bedded phreatomagmatic debris and incised in sedimentary basements. [NOTE: We use the word 'vent' following Jackson, 1997: "the opening at the Earth's surface through which volcanic materials are extruded; also, the channel or conduit through which they pass".] Such complexes have so far been documented only in the Karoo large igneous province (McClintock et al., 2003) and the Ferrar province (White and McClintock, 2001; Ross and White, 2003).

The Mawson Formation at Coombs Hills, Antarctica (Ferrar province) provides an outstanding example of such a debris-filled vent complex (Fig. 1). McClintock and White (2005), using field data collected by McClintock (2001) and White (unpublished), have recently given a complete interpretation of the origin of the vent complex as a whole and of the individual lithofacies present. Most importantly, in the context of this paper, they introduced the notion of subterranean debris jets, i.e. "jets of debris, magmatic gases, and water vapour +/- liquid water" that never reach the surface, as a transport phenomenon important in phreatomagmatic vent complexes. In particular, McClintock and White (2005) proposed that cross-cutting zones of volcaniclastic rocks, having a contrasting componentry relative to their host in the vent complex, had been formed by such debris jets (some of which may have remained subterranean, others of which produced subaerial deposits).

Given the excellent outcrop quality and the great internal variability of the Coombs Hills complex, it was decided revisit it in order to carry out a more detailed study of areas containing several cross-cutting lapilli-tuff and tuff-breccia zones (Ross, 2005). First, the central half of the complex was remapped to quantify the proportion of the different lithofacies present (Table 1, 
Fig. 2) and to describe their contact relationships. Then, efforts were concentrated on precisely mapping, and measuring the componentry of, the cross-cutting zones of non-bedded lapilli-tuff and tuff-breccia in two relatively small but interesting areas (Figs. 3-4). Herein the size, shape and origin of these sub-vertical debrisfilled zones are discussed. We concur with McClintock and White (2005) that many (but not all) of these crosscutting zones were produced by debris jets propelled by violent magma-aquifer interactions, and elaborate on the nature of these jets and their interactions with surrounding pre-existing volcaniclastic material.

\subsection{Geological setting}

The Jurassic Ferrar large igneous province is distributed in the Transantarctic Mountains (Elliot, 1992; Fig. 1a), southern Australia (Hergt and Brauns, 2001) and New Zealand (Mortimer et al., 1995). The combined Karoo and Ferrar have an estimated original volume of $\sim 1.5 \times 10^{6} \mathrm{~km}^{3}$ (Eldholm and Coffin, 2000). Rocks of the Ferrar province comprise: (1) mafic intrusions (sills and dikes of the Ferrar Dolerite, plus the Dufek and Forrestal layered intrusions; Gunn and Warren, 1962; Kyle et al., 1981; Ford and Himmelberg, 1991; Fleming et al., 1997; Ferris et al., 1998); (2) flood lavas of the Kirkpatrick Basalt (Grindley, 1963; Elliot, 1972, Elliot et al., 1986a, 1999); (3) mafic volcaniclastic deposits underlying the flood lavas (details to follow). At the present level of erosion of the Ferrar province, intrusive rocks predominate greatly in the preserved rock volume (Ross et al., 2005). Lavas in the Kirkpatrick Basalt, and 'basaltic' fragments in the volcaniclastic deposits, are mostly basaltic andesite in composition (e.g., Elliot, 1972; Siders and Elliot, 1985; Ross, 2005), but lavas and clasts are nevertheless referred to as 'basaltic', in keeping with historical usage.

Prior to the beginning of Ferrar magmatism, a sedimentary sequence known as the Beacon Supergroup underlay the surface of the area (Barrett, 1991). This sedimentary sequence is divided into the Devonian Taylor Group and the Permian-Triassic Victoria Group, the uppermost part of which is called the Lashly Formation in South Victoria Land. Rare tuff megaclasts and locally dispersed silicic glass shards in Coombs Hills deposits (Ross, 2005) show that fine-grained silicic tuffs or tuffaceous sandstones once were included in, or overlay, the uppermost Victoria Group in South Victoria Land, as they do in the Central Transantarctic Mountains (Elliot, 1996; Elliot et al., 2004). Whether these silicic deposits are genetically part of the Ferrar province is not clear at this stage (cf. Bryan et al., 2002).

The mafic volcaniclastic rocks of the Ferrar province are referred to as the Prebble Formation in the Central Transantarctic Mountains (Hanson and Elliot, 1996; Elliot and Hanson, 2001), the Mawson Formation in South Victoria Land (Gunn and Warren, 1962; Ballance and Watters, 1971; Grapes et al., 1974; Korsch, 1984; Bradshaw, 1987; McClintock, 2001), and the Exposure Hill Formation in North Victoria Land (Elliot et al., 1986b). The maximum thickness of mafic volcaniclastics known in these three regions is about $360 \mathrm{~m}, 400 \mathrm{~m}$ and $100 \mathrm{~m}$, respectively (Elliot, 2000; Fig. 1b). The hypothetical former extent of the Mawson
Formation is shown on Fig. 1c; it forms a belt truncated by erosion to the east and disappearing beneath the present-day ice of the polar plateau to the west. The area exposing the thickest Mawson deposits is the CoombsAllan Hills region; the Mawson Formation at Allan Hills was most recently described in papers by Reubi et al. (2005) and Ross and White (2005a).

\section{Description of the Mawson Formation in the field} area

The total surface area occupied by the Mawson Formation at Coombs Hills is about $28.5 \mathrm{~km}^{2}$, of which about $48 \%$ was re-mapped in more detail (Ross, 2005; Fig. 1d). North of Mt Brooke, the volcaniclastic rocks consist dominantly of coarse, poorly sorted, non-bedded deposits interpreted to fill a vent complex (White and McClintock, 2001; McClintock and White, 2005). Nonbedded rocks are overlain by a bedded sequence in the Pyramid area and by local tuff ring-style deposits (Fig. 2, Table 1). The Pyramid sequence has been described in some detail by McClintock and White (2005), whereas the tuff ring-style deposits will be discussed elsewhere.

The dominant volcaniclastic facies in the field area is a poorly sorted, non-bedded, heterolithologic lapilli-tuff (facies code $\mathrm{LT}_{\mathrm{h}}$, see Table 2 for description and interpretation). These rocks host cross-cutting bodies of other non-bedded volcaniclastic rocks (Figs. 3-4; details below), volcaniclastic dikes (Ross and White, 2005b), and two types of rafts (Table 3). Large basaltic plugs and swirly basaltic dikes are also present in the vent complex, but will be discussed elsewhere. The remainder of this section focuses on the non-bedded volcaniclastic rocks; first, their grain size and componentry, then the field aspect, size and shape of steep-sided cross-cutting zones.

\subsection{Grain size and componentry of non-bedded volcaniclastic rocks}

The main constituents of all these rocks are glassy basalt clasts (ash to block size), Beacon sedimentary rock fragments (ash to block size), sand-grade detrital quartz grains derived from the Beacon sequence, finely crystalline basalt fragments (ash to block size) and "composite" clasts (lapilli to block size), in variable proportions. Field photographs, grain size and componentry data based on field clast counts, photomicrographs, and petrographic point counts for the different non-bedded, poorly sorted lithofacies in the vent complex are presented in Figs. 5-7.

Glassy basalt clasts. These are mostly nonvesicular to poorly vesicular and can be divided into three main macroscopic types: (i) medium to dark brown clasts with blocky shapes; (ii) pale grey/brown to cream clasts with sub-round, locally amoeboid shapes; (iii) elongate "raggy" clasts, which sometimes are aligned. Type (i) clasts, which are the most abundant type of glassy basalt fragments in $\mathrm{LT}_{\mathrm{a}}, \mathrm{LT}_{\mathrm{h}}$ and $\mathrm{LT}_{\mathrm{o}}$ (see Table 2 for explanation of all facies codes) are mostly of small lapilli size, whereas the other types are larger on average (about $1-2 \mathrm{~cm}$ for type ii and $>5 \mathrm{~cm}$ for type iii). Very locally the amount of "rags" (type iii) increases substantially, forming a "raggy" tuff-breccia $\left(\mathrm{TB}_{\mathrm{hr}}\right)$. Overall glassy basalt clasts are interpreted as rapidly 
cooled juvenile fragments, but the proportions that are "first-cycle" versus recycled (Houghton and Smith, 1993) have not been determined.

Country rock fragments. Sedimentary rock fragments represent all types of rock present in the Victoria Group (upper half of the Beacon sequence); medium- and coarse-grained sandstone fragments are more abundant in the block fraction, whereas the finergrained Beacon rocks (coal, mudstone, fine-grained sandstone) are better represented in the lapilli and ash fraction. Very rare blocks of unfoliated granite were observed, up to $1 \mathrm{~m}^{3}$ in volume, generally rounded to sub-rounded in shape, and comprising K-feldspar > quartz $>$ plagioclase $>$ biotite \pm hornblende(?) with a sub-equigranular texture.

Finely crystalline basalt fragments. These are dark brown, mostly angular and non-vesicular, but locally are more round or display up to $40 \%$ vesicles. They are found as inclusions in some larger composite clasts (see below) and in glassy basaltic clasts, indicating they are somewhat older than most of the composite and glassy basaltic clasts; they could represent pieces of already solidified basaltic intrusions rather than juvenile material.

Composite clasts. Such clasts include cored bombs (core of basalt or Beacon sedimentary rock, surrounded by a rind of glassy basalt), and fragments of peperite. The latter have a round to amoeboid shape and can measure several metres across.

Ash fraction. Among detrital minerals, angular quartz is the most abundant, as opposed to rounded quartz, micas, or feldspar (Fig. 6a; Fig. 7, lower left). Most ash-grade basaltic clasts are non-vesicular to incipiently vesicular (vesicularity index of Houghton and Wilson, 1989), although some have more vesicles, in particular in the basalt-rich facies $\mathrm{TB}_{\mathrm{hr}}$ and $\mathrm{TB}_{\mathrm{j}}$ (Figs. $6 \mathrm{~b}$ and 7).

\subsection{Cross-cutting zones of non-bedded volcaniclastic rocks}

Four main types of non-bedded cross-cutting bodies can be distinguished in the field area: the basaltrich tuff-breccias or lapilli-tuffs $\left(\mathrm{TB}_{\mathrm{j}}\right)$, themselves divided into two sub-types; the Beacon-rich lapilli-tuffs or tuff-breccias $\left(\mathrm{LT}_{\mathrm{a}}\right)$; and the "raggy" heterolithologic tuff-breccias $\left(\mathrm{TB}_{\mathrm{hr}}\right)$. Domains of the latter type have boundaries that are gradational and many meters wide with host $\mathrm{LT}_{\mathrm{h}}$ (Table 2); they are not addressed further here (see Ross, 2005).

$\boldsymbol{L} \boldsymbol{T}_{\boldsymbol{a}}$ zones. These have a pale to medium grey colour, a significantly larger proportion of Beacon fragments than facies $\mathrm{LT}_{\mathrm{h}}$ (Fig. 5), and form several clusters in the field area. The host for $\mathrm{LT}_{\mathrm{a}}$ zones generally is facies $\mathrm{LT}_{\mathrm{h}}$, except in map A (Fig. 3) where it is $\mathrm{LT}_{\mathrm{o}}$ (Table 2). Each cluster of $\mathrm{LT}_{\mathrm{a}}$ zones comprises at least five individual zones, and generally the more zones in a cluster, the smaller their sizes: the most extreme case is a cluster of $>20$ zones, each smaller than $1 \mathrm{~m}^{2}$ in surface area.

If $\mathrm{LT}_{\mathrm{a}}$ zones occur within any given $200 \times 200 \mathrm{~m}$ area, one can also expect to find at least one $\mathrm{TB}_{\mathrm{j}} \mathrm{zone}$, but the reverse proposition is not always true. Beacon rafts (Table 3) are spatially associated with $\mathrm{LT}_{\mathrm{a}}$ zones in map C, but not in map A; furthermore, the sandstone in Beacon rafts has a distinct yellow-cream colour, whereas the sandstone clasts in $\mathrm{LT}_{\mathrm{a}}$ zones (and their $\mathrm{LT}_{\mathrm{h}}$ host) are invariably pale to medium grey. Therefore no genetic relationship is inferred between $\mathrm{LT}_{\mathrm{a}}$ zones and Beacon rafts (cf. McClintock, 2001).

The overall volume of facies $\mathrm{LT}_{\mathrm{a}}$ rocks within the field area appears very small, less than $1 \%$ (Table 1; maps $\mathrm{A}$ and $\mathrm{C}$ do not represent of the overall abundance of $\mathrm{LT}_{\mathrm{a}}$ zones). These zones are nevertheless important, because they exemplify one compositional end-member (Beacon-rich) of the cross-cutting bodies of volcaniclastic rocks. They also illustrate a widespread process in Coombs Hills. Our observations indicate that cross-cutting $\mathrm{LT}_{\mathrm{h}}$ bodies of similar geometry are ubiquitous throughout Coombs Hills, but they are virtually unmappable. This is because there is no mechanical or weathering contrast between rocks formed by emplacement of an $\mathrm{LT}_{\mathrm{h}}$ body into an $\mathrm{LT}_{\mathrm{h}}$ host, and the zone boundaries are hence only locally, and always very subtly, apparent in outcrop.

The mean equivalent diameter of $\mathrm{LT}_{\mathrm{a}}$ zones in maps $\mathrm{A}$ and $\mathrm{C}$ is 9.4 and $11.2 \mathrm{~m}$, respectively, with standard deviations of $6.6 \mathrm{~m}$ in both cases (data on Figs. 3-4). In map view, the most common shape of $\mathrm{LT}_{\mathrm{a}}$ zones is an ellipse, although three- to seven-sided polygons with rounded corners are also found in map A. The anisometry (short axis/long axis of the best-fitting ellipse) values for $16 \mathrm{LT}_{\mathrm{a}}$ zones range from 0.19 to 0.84 (mean $=0.6$, st. dev. $=0.2$ ). Ellipses having anisometry values between 0.2 and 1.0 are shown on Fig. 8a for comparison. Shape factors for $\mathrm{LT}_{\mathrm{a}}$ zones are plotted against their anisometry on Fig. 8c; the shape factors of a number of objects are shown on Fig. 8b for comparison. Relative to sandstone rafts, some $\mathrm{LT}_{\mathrm{a}}$ zones are simpler, and some are more irregular.

The dip of $\mathrm{LT}_{\mathrm{a}}$ zones may be difficult to measure on sub-horizontal outcrops, but since they erode more readily than their host $\mathrm{LT}_{\mathrm{h}}$, they generally form shallow topographic depressions (Fig. 9a). The appearance of these depressions suggests sub-vertical contacts, so the $3 \mathrm{D}$ shape of many of these zones is most likely a subvertical pipe. Whether they are cylindrical or they flare upwards is difficult to tell. From a distance, the contacts between the $\mathrm{LT}_{\mathrm{a}}$ zones and their (predominantly) $\mathrm{LT}_{\mathrm{h}}$ host appear very sharp due to the abrupt change of overall colour and componentry. Locally, examination of contacts reveals centimetre-scale undulations, with $\mathrm{cm}$ to dm-scale projections of host into younger $\mathrm{LT}_{\mathrm{a}}$ (Fig. 5, middle photograph).

$\boldsymbol{T B}_{j}$ zones. Non-bedded $\mathrm{TB}_{\mathrm{j}}$ and associated basalt pods and peperite domains dominate the northern West Ridge and the Windy Ridge (Fig. 2), resulting in a combined surface area $\left(\mathrm{TB}_{\mathrm{j}}+\right.$ peperite domains + basalt pods) of a little under $19 \%$ of the field area (Table 1). They also occur elsewhere as metre- to hundreds of metre-wide bodies invading $\mathrm{LT}_{\mathrm{h}}$ or $\mathrm{LT}_{\mathrm{o}}$ hosts (e.g., map A and map C).

Facies $\mathrm{TB}_{\mathrm{j}}$ is a non-bedded, poorly sorted tuffbreccia (locally lapilli-tuff) comprising less than 5\% Beacon fragments in the lapilli + block size fraction (the remaining fragments are basaltic; Fig. 5). TB $_{\mathrm{j}}$ at Coombs Hills almost always contains a few sand-sized quartz 
grains visible with a hand-lens, even though this is the most basalt-rich facies of all. These basalt-rich zones, which are up to hundreds of metres across, resist erosion better than other facies and therefore form positive topography of up to $1 \mathrm{~m}$ relative to their host (after erosion), revealing sub-vertical contacts.

The equivalent diameters of $\mathrm{TB}_{\mathrm{j}}$ zones (Fig. 9b) in maps $\mathrm{A}$ and $\mathrm{C}$ are at least twice as large as both the median and the mean diameter (about $10 \mathrm{~m}$ ) of $\mathrm{LT}_{\mathrm{a}}$ zones. The shapes of $\mathrm{TB}_{\mathrm{j}}$ zones are more complex than those of $\mathrm{LT}_{\mathrm{a}}$ zones, with dike-like protrusions and centimetre- to tens of metre-scale undulation of contacts (e.g., map A). The shape factors of the $\mathrm{TB}_{\mathrm{j}}$ zones in map $A$ are lower than any others measured at Coombs Hills, confirming the highly irregular (tortuous) nature of the perimeters (Fig. 8c).

Two subtypes of $\mathrm{TB}_{\mathrm{j}}$ zones are distinguished; these types are end-members and some zones display transitional characteristics. The first type of $\mathrm{TB}_{\mathrm{j}}$ zone is characterized by relatively sharp contacts with the host, and relatively compact shapes (e.g., some East Ridge zones). They contain the same types of clasts as their $\mathrm{LT}_{\mathrm{h}}$ host, but with more abundant basaltic fragments; blocky basalt clasts are present in notable proportions. These type (1) $\mathrm{TB}_{\mathrm{j}}$ zones are not strongly associated with basalt pods and/or in situ peperite domains, although they contain peperite fragments (composite clasts).

The second type of $\mathrm{TB}_{\mathrm{j}}$ zone, which is very abundant on the West and Windy ridges (Fig. 2), generally has diffuse gradational contacts with the host; where outlines are sharp, outlines can be very complex (e.g., octopus-like, Fig. 3). These type (2) $\mathrm{TB}_{\mathrm{j}}$ zones contain fluidal basalt fragments and composite clasts, with few or no blocky clasts, and they are spatially associated with in situ peperite domains, and/or pods of glassy basalt. Gradational transitions between a central basalt pod, a peperite zone and finally $\mathrm{TB}_{\mathrm{j}}$ are typical (see also McClintock and White, 2005 for more on peperites at Coombs Hills).

\section{Origin of cross-cutting zones of non-bedded volcaniclastic rocks}

The overall interpretation for the Mawson Formation north of Mt Brooke is that it represents a phreatomagmatic vent complex or "phreatocauldron" this is justified here for $\mathrm{LT}_{\mathrm{h}}$ in Table 2, but see also White and McClintock (2001) and McClintock and White (2005). The full argument will not be presented again here, and even if the Mawson Formation did not fill a vent complex at Coombs Hills, the interpretation of the cross-cutting zones of non-bedded volcaniclastic rocks - the focus of this paper - would not change significantly. $\mathrm{LT}_{\mathrm{a}}$ and $\mathrm{TB}_{\mathrm{j}}$ zones cross-cut $\mathrm{LT}_{\mathrm{h}}$, so they were emplaced after $\mathrm{LT}_{\mathrm{h}}$, and the knowledge of how the host was generated is not a prerequisite for interpreting the origin of the cross-cutting bodies.

Forcible emplacement from below. Since the bulk of the Coombs Hills deposits, primarily $\mathrm{LT}_{\mathrm{h}}$, were already in place when the mapped cross-cutting zones were generated, no explanation of these zones that involves lateral flow of debris on the ground surface (lahars, pyroclastic flows, etc.) can be seriously considered. The debris now filling the cross-cutting zones was travelling sub-vertically, either from below or from above. A filling-from-above origin, independent of any volcanic activity, would imply that $\mathrm{LT}_{\mathrm{h}}$ material was able to sustain significant open holes for long periods of time - this appears very unlikely given that the $\mathrm{LT}_{\mathrm{h}}$ material was not consolidated during emplacement of the cross-cutting zones, as indicated by a lack of grain truncations and the granular interfingering along contacts. Also, it appears that the $\mathrm{LT}_{\mathrm{h}}$ material was able flow into and deform newly emplaced $\mathrm{LT}_{\mathrm{a}}$ bodies after their emplacement (Fig. 5, middle photo, see left of the pencil). Therefore, the only viable origins for the crosscutting zones are forcible emplacement from below ("intrusion"), or rapid sedimentation inside a transient gas-and/or vapour-filled 'cavity' related to volcanic activity.

Debris jets. As mentioned earlier, McClintock and White (2005) introduced the concept of subterranean debris jets to describe the upward-directed movement of volcaniclastic debris inside volcanic vents. Such jets could very well exit the vents, expanding and becoming visible as subaerial tephra jets, but debris jets are not required to exit the vents and can remain subterranean throughout their existence.

The expected trace of the passage of a debris jet in a debris-filled volcanic vent - regardless of the ultimate fate of the jet, i.e. wholly subterranean or becoming subaerial - is a pipe-like structure filled with non-bedded volcaniclastic material. This pipe will only be visible in outcrop (after the overlying rocks are eroded) if the material filling it is of a componentry sufficiently different from that of the volcaniclastic host to display a clear visual or mechanica/weathering contrast. This is why it is possible to map cross-cutting zones which are basalt-rich $\left(\mathrm{TB}_{\mathrm{j}}\right)$ or Beacon-rich $\left(\mathrm{LT}_{\mathrm{a}}\right)$ emplaced into a $\mathrm{LT}_{\mathrm{h}}$ host at Coombs Hills, but not, for example, $\mathrm{LT}_{\mathrm{h}}$ pipes emplaced into a $\mathrm{LT}_{\mathrm{h}}$ host.

Debris jets propelled by phreatomagmatic explosions. The material now preserved in the $\mathrm{LT}_{\mathrm{h}}$ host - as well as that filling $\mathrm{LT}_{\mathrm{a}}$ pipes and type $1 \mathrm{~TB}_{\mathrm{j}}$ zones is inferred to be of phreatomagmatic origin because of its high content of country rock debris, the common blocky shape and low average vesicularity of juvenile clasts, and the wide range of vesicularity found in these clasts (Table 2 \& references cited therein). For $\mathrm{LT}_{\mathrm{a}}$ pipes, explosions would have taken place near, or within, country rocks to explain the great abundance of Beacon Supergroup clasts. Elastic waves (Büttner and Zimanowski, 1998; Raue, 2004) fragmented country rocks to such an extent that Beacon fragments and sandsize quartz grains dominated the debris jets which formed $\mathrm{LT}_{\mathrm{a}}$ pipes. In contrast, for type (1) $\mathrm{TB}_{\mathrm{j}}$ zones, the basaltic dikes feeding them would have interacted with existing wet $\mathrm{LT}_{\mathrm{h}}$ material, well away from any source of supplementary Beacon fragments. Since new basalt was fragmented and made available, but no new country rock fragments, the resulting debris jets would have been more basalt-rich than the surrounding $\left(\mathrm{LT}_{\mathrm{h}}\right)$ host. We elaborate on the relationship of cross-cutting zone geometry to, and the character of, debris jets propelled by magma-aquifer explosive interaction in section 4 below. 
What proportion of the glassy basaltic clasts are first-cycle juvenile fragments? To achieve the correct mix of basaltic clasts and Beacon material (sedimentary rock clasts and detrital grains) for a typical $\mathrm{LT}_{\mathrm{a}}$ composition (say 70\% Beacon, 30\% glassy basalt), one could mix one part $\mathrm{LT}_{\mathrm{h}}$ material (containing, for the sake of argument, 30\% Beacon material and 70\% glassy basalt fragments) with 1.33 parts of newly fragmented Beacon rocks; this would imply an absence of true juvenile material in $\mathrm{LT}_{\mathrm{a}}$ (which seems unlikely). At the other extreme, if no existing $\mathrm{LT}_{\mathrm{h}}$ material is incorporated in jets, one could obtain the correct $\mathrm{LT}_{\mathrm{a}}$ componentry by mixing $70 \%$ pure Beacon source and $30 \%$ basalt clasts formed by the rapid cooling and fragmentation of new magma (first-cycle juvenile clasts). Considering simultaneous recycling of pre-existing volcaniclastic debris and creation of new juvenile clasts, the proportion of first-cycle juvenile material for $\mathrm{LT}_{\mathrm{a}}$ pipes would be between zero and 30\%, with observations in Feistmantel Valley at central Allan Hills favouring the higher value (see Ross, 2005). By extension, the proportion of new juvenile material formed by other phreatomagmatic explosions at Coombs Hills (i.e., those that formed the other facies of non-bedded rocks) might be in the same range. So if a particular explosive interaction produces as little as $10 \%$ of the material propelled, the resulting deposits filling the new pipe would look very similar to the surrounding rocks, probably without systematically clear-cut, mappable, contacts. In the context of a vent complex, such "LT $\mathrm{T}_{\mathrm{h}}$ pipes within $\mathrm{LT}_{\mathrm{h}}$ host" are believed to explain ubiquitous lateral variation in componentry, at meters to tens of meters scale, with only subtle and discontinuous contacts, within the $\mathrm{LT}_{\mathrm{h}}$ deposits. Postdepositional shaking or movement of the granular deposits would have the effect of further diffusing and blurring the boundaries.

Type (2) basalt-rich zones. $\mathrm{TB}_{\mathrm{j}}$ zones of the second type have several characteristics that support a different origin than that proposed for the first type Table 4 lists these characteristics and gives our favoured interpretation of these zones.

\section{Phreatomagmatic debris jets}

Processes within the vents of erupting volcanoes are at present impossible to study in situ, but aspects of features within active vents and their dynamics can be interpreted from deposits. We infer that the cross-cutting zones of non-bedded volcaniclastic material we have mapped in detail are a product of the passage of debris jets, but that they probably do not represent "frozen jets"; one needs to distinguish the transport system (debris jets) from the depositional system (poorly constrained at this stage). Regarding the transport system, the particle concentration in the jets, the proportion of liquid water versus vapour in the interstitial fluids, the velocity of particles in the jets, and the nature and intensity of interactions between jets and their host, above the explosion sites, are all unknown. Kokelaar (1983) presented a model for Surtseyan tephra jets (at Surtsey specifically), but we propose that the debris jets produced by magma-aquifer interaction behave differently than those at Surtsey.

\subsection{Jet-host interaction}

In Kokelaar's (1983) model, the "slurry" around the underground part of a jet is continuously incorporated and mixed into the proto-jet as it rises. This is to some degree because the vent fill at Surtsey was interpreted (by Kokelaar) as being at least partially fluidised, and effects such as velocity shear and acceleration of fluid-fluid boundaries cause mixing and incorporation of the vent fill at the margins of the rising proto-jet.

At Coomb Hills, by contrast, we propose that interactions between vent-filling debris and jets of material being propelled through it were minimal, once focussed subterranean jets were formed. After the material above the explosion sites was cleared away to open transient conduits, the jets interacted little with their surroundings, at least at the elevations now exposed in outcrop (Fig. 10). This can be inferred because the grain size and componentry transition between $\mathrm{LT}_{\mathrm{a}}$ pipes and their surroundings is always very abrupt. Should fragments from the host have been entrained during transport in the jet, it is expected that the margins of the $\mathrm{LT}_{\mathrm{a}}$ pipes would be richer in basaltic clasts (derived from the $\mathrm{LT}_{\mathrm{h}}$ host) than the interior of the pipes - this is not the case.

Another observation substantiating the idea that debris jets do not interact strongly with their host is a completely distinct population of Beacon fragments in $\mathrm{LT}_{\mathrm{a}}$ pipes versus Beacon fragments in the surrounding breccias in Feistmantel Valley at central Allan Hills (these pipes were labelled "BX5" by Ross, 2005). Again, should interaction between the debris jets and the host have been strong, one would expect to see at least partial correspondence in the lithology of Beacon fragments between $\mathrm{LT}_{\mathrm{a}}$ zones and the adjacent host, especially near the margins of the zones - this is not the case (rather, the Beacon fragments in $\mathrm{LT}_{\mathrm{a}}$ zones were derived from deeper levels).

Given the relative homogeneity of the pyroclasts at Surtsey and similar emergent volcanoes (juvenile particles with only minor marine sediments, e.g. Thorarinsson et al., 1964; Lorenz, 1974; Moore, 1985), it is difficult to obtain data regarding the significance of entrainment, whereas for eruptions whose products contain abundant lithic fragments from a known stratigraphy such data is readily obtained (e.g., Valentine and Groves, 1996). In Surtseyan deposits, only recognisably recycled clasts (Houghton and Smith, 1993), composite clasts (White and McClintock, 2001) or recapitulated clasts (Rossell et al., submitted) have the potential to further address this question.

\subsection{End-member cases of jet behaviour}

Our model for Coombs Hills can be placed into a deductive matrix of end-member cases of debris jet behaviour (Table 5, Fig. 11). Three cases involve relatively dense jets (high particle concentration) and the other three involve relatively dilute jets. The bottom cartoons of Fig. 11 show the upper part of the jets, well above the explosion sites; the top cartoons show the situation after a surface deposit has been formed (this is optional), the jets have stopped moving, and the gas phase has condensed or escaped. We are interested by 
the nature of the surface deposit (if any), the nature of the material filling the jet passageway after jet motion has ceased, and jet-host interaction during the jet's passage.

In cases 1.1 and 1.2 , the jet propagates by pushing the host material upwards and removing it from the site. Once the conduit has been cleared, the jet can then flow freely with no further interaction with the host. This should produce a surface deposit consisting of two sharply distinct layers: the first layer will consist exclusively of shallow host particles ejected ahead of the driving jet (unfilled circles on Fig. 11), whereas the overlying layer will consist only of deep-sourced jet material (filled circles). The conduit will be occupied by deep-sourced material, given that the shallow host has been cleared entirely. Since the host does not "rebound", the conduit collapses to some extent at the end; this effect is more important in the dilute jet case because of the wider passageway cleared (case 1.2).

In cases 2.1 and 2.2, the jet propagates upwards by entraining host debris, abrading particles from the conduit walls, and mixing everything together. Initially, the upper part of the jet will contain of a mixture of particles from the shallow host (unfilled circles), and deep-sourced debris (filled circles). Deeper down, the jet will consist exclusively of deep-sourced material. This vertically zoned jet should produce a vertically zoned surface deposit: the first layer will contain material from both the shallow host and deeper down, and the second layer will contain only deep-sourced particles. The conduit will be also be filled by deep-sourced material only (especially if the jet has propagated to the surface and produced the mentioned subaerial deposits). As for cases 1.1 and 1.2, conduit collapse will occur because the host cannot sustain steep unsupported conduit walls.

Finally, in cases 3.1 and 3.2, - which seem physically implausible but which we include for the sake of completeness - the granular host is assumed to deform without erosion, by somehow "splitting apart" or deforming sideways to let the jet pass; there is no removal of host or mixing between the host and the jet at the levels shown. Since the host "bounces" back laterally when the jet ceases to move (and loses most of its gas phase), there is no or very little opportunity for conduit collapse (i.e. downward movement of material along the margins of the transient conduit). The surface deposit, and the conduit fill, will consist exclusively of deepsourced material (filled circles on Fig. 11), because the shallow host material has not been mobilised in any way.

In cases 3.1 and 3.2, or in other cases if the jet is sustained long enough, no particles from the immediately adjacent host will be clearly discernable in the homogeneous conduit fill, matching observations in $\mathrm{LT}_{\mathrm{a}}$ pipes at Coombs Hills and central Allan Hills. We cannot, unfortunately, correlate specific subaerial deposits with specific debris-filled pipes at Coombs Hills to deduce which end-member case in Fig. 11 is more likely.

We infer that in reality debris jets show different end-member behaviour at different points in their upward passage. Adjacent to the initial explosion site, some recoverable movement (cases 3.1 or 3.2) of the explosion host probably occurs, though it is unlikely to be of great significance. As the jet extends upward with early expansion, a relatively broad passageway would be forced through enclosing host material (1.2); as the jet elongates upward there is greater opportunity for entrainment of debris from the wall of the passageway (case 2.2), which will widen or narrow depending on the balance of gas pressure in the jet versus the susceptibility of the passageway walls to collapse. Either loss of gas into permeable passageway walls, or condensation of magmatic or aquifer derived steam, would reduce gas volume and pressure in the jet, making it more dense (cases 1.1 or 2.1 ).

Experimental studies with analogue materials are now planned to better assess how subterranean debris jets propagate and behave; interpretation of experimental results will be constrained by the field results and analytical framework presented and developed here.

\section{Summary and conclusions}

The bulk of the Mawson Formation north of Mt Brooke at Coombs Hills is non-bedded and consists of poorly sorted lapilli-tuffs and tuff-breccias. The volumetrically dominant facies is a heterolithologic lapilli-tuff $\left(\mathrm{LT}_{\mathrm{h}}\right)$, consisting of formerly glassy basalt fragments (mostly blocky ones), sand-grade detrital quartz particles, Beacon sedimentary rocks, composite clasts, and rare granite. The basaltic clasts, now altered to palagonite and clays, are variably vesicular, most being dense to incipiently vesicular. The clast assemblage suggests phreatomagmatic eruptions affecting the upper part of the Beacon sequence, occasionally as far down as the base of the Victoria Group.

On the basis of (1) a lack of bedding planes for over 300 vertical metres, (2) a lack of vertical changes in componentry and grain size, (3) the presence of steeply dipping rafts, and (4) lateral changes in grainsize and componentry, the best explanation for the genesis of $\mathrm{LT}_{\mathrm{h}}$ rocks is emplacement in a vent complex. Several cycles of eruption are probably indicated by the proportions of glassy basalt clasts observed in $\mathrm{LT}_{\mathrm{h}}$ if the starting point was phreatomagmatic explosions in a Lashly Formation (uppermost Beacon Supergroup) aquifer.

Poorly sorted, non-bedded, Beacon-rich lapillituffs or tuff-breccias $\left(\mathrm{LT}_{\mathrm{a}}\right)$ consisting of the same types of clasts as in $\mathrm{LT}_{\mathrm{h}}$ but in different proportions, form steep to vertical, pipe-like bodies cross-cutting other non-bedded volcaniclastic rocks. These pipes are interpreted as having been formed due to passage of Beacon-rich debris jets. Such jets originated when phreatomagmatic explosions occurred near the walls or floor of the vent complex, causing fragmentation of abundant country rock material. We infer that once focussed jets were formed, they did not incorporate significant amounts of existing Mawson debris while travelling through them; rather, incorporation of fragments from the $\mathrm{LT}_{\mathrm{h}}$ host (existing, non-lithified volcaniclastic material) took place near explosion sites.

$\mathrm{TB}_{\mathrm{j}}$ facies rocks are non-bedded tuff-breccias or lapilli-tuffs with less than $5 \%$ Beacon clasts in the lapilli and block size fractions. $\mathrm{TB}_{\mathrm{j}}$ bodies containing blocky juvenile fragments and not strongly associated with basalt pods and/or peperite domains could have formed 
when phreatomagmatic interactions took place within existing $\mathrm{LT}_{\mathrm{h}}$ debris, well away from country rocks, so that the debris jets would have been richer in basalt than surrounding material. As is the case for $\mathrm{LT}_{\mathrm{a}}$ pipes, it is inferred that interactions between the host and these jets of material being propelled through it were minimal (once focussed jets were established).

In contrast, other non-bedded $\mathrm{TB}_{\mathrm{j}}$ zones (e.g, on the West and Windy Ridges) are spatially and genetically associated with in situ peperite domains and basalt pods. Basaltic clasts in these $\mathrm{TB}_{\mathrm{j}}$ zones are often fluidal in shape rather than blocky; more composite clasts are present than in any other facies. These observations suggest a somewhat less violent origin than for $\mathrm{LT}_{\mathrm{a}}$ and $\mathrm{LT}_{\mathrm{h}}$, with non-explosive processes such as shearing of magma during movement of pore water and fluidised 'sediment' (here pre-existing volcaniclastic debris), surface tension effects, magma-sediment density contrasts, and instabilities in vapour films, possibly playing some role in juvenile clast generation. Also, mixing between the granular host and newly-formed basaltic clasts was an essential part of the genesis of these zones.

We have introduced a matrix of end-member cases of debris jet behaviour, considering mechanisms of jet propagation and possible responses of the host material. A scenario developed with reference to these end-member behaviours is suggested as a likely, but not demonstrable, train of events during debris-jet passage and deposit emplacement that involves initial minor recoverable displacement at the site of jet origin, upward and lateral removal of material during expansive early jet growth, with greater opportunity for entrainment from passageway walls and increased jet density as the jet extends with potential loss or condensation of gas.

\section{Acknowledgements}

Our work at Coombs Hills was supported by Antarctica New Zealand, the University of Otago (research grants to White and $\mathrm{PhD}$ scholarship to Ross) and the Fonds de recherche sur la nature et les technologies (Quebec, Canada). J. Cottle served faithfully as field guide, while A. Aitken and M. Baker were field assistants. We thank D. Walls, B. Pooley and S. Read for technical support, and M.K. McClintock for discussions on vent complexes in the Ferrar and Karoo provinces. Helpful comments on the submitted typescript by V. Lorenz and an anonymous reviewer are acknowledged.

\section{References}

Ballance, P.F., Watters, W.A., 1971. The Mawson Diamictite and the Carapace Sandstone, formations of the Ferrar Group at Allan Hills and Carapace Nunatak, Victoria Land, Antarctica. N. Z. J. Geol. Geophys. 14, 512-527.

Barberi, F., Cioni, R., Rosi, M., Santacroce, R., Sbrana, A., Vecci, R., 1989. Magmatic and phreatomagmatic phases in explosive eruptions of Vesuvius as deduced by grainsize and component analysis of the pyroclastic deposits. J. Volcanol. Geotherm. Res. 38, 287-307.

Barrett, P.J., 1991. The Devonian to Jurassic Beacon Supergroup of the Transantarctic Mountains and correlatives in other parts of Antarctica. In: Tingey, R.J.
(Ed.), The Geology of Antarctica. Oxford University Press, Oxford, pp. 120-152.

Bradshaw, M.A., 1987. Additional field interpretation of the Jurassic sequence at Carapace Nunatak and Coombs Hills, south Victoria Land, Antarctica. N. Z. J. Geol. Geophys. 30, 37-49.

Bryan, S.E., Riley, T.R., Jerram, D.A., Stephens, C.J., Leat, P.L., 2002, Silicic volcanism: An undervalued component of large igneous provinces and volcanic rifted margins. In: Menzies, M.A., Klemperer, S.L., Ebinger, C.J., Baker, J. (Eds.), Volcanic Rifted Margins. Geol. Soc. Am. Special Paper 362, pp. 97-118.

Busby-Spera, C.J., White, J.D.L., 1987. Variation in peperite textures associated with differing host-sediment properties. Bull. Volcanol. 49, 765-775.

Büttner, R., Zimanowski, B., 1998. Physics of thermohydraulic explosions. Phys. Rev. E 57, 5726-5729.

Eldholm, O., Coffin, M.F., 2000, Large igneous provinces and plate tectonics. In: Richards, M.A., Gordon, R.G., van der Hilst, R.D. (Eds.), The History and Dynamics of Global Plate Motions. Am. Geophys. U., Geophysical Monograph 121, pp. 309-326.

Elliot, D.H., 1972. Major oxide chemistry of the Kirkpatrick Basalt, Central Transantarctic Mountains. In: Adie, R.J. (Ed.), Antarctic Geology and Geophysics. Universitetsforlagets, Oslo, pp. 413-418.

Elliot, D.H., 1992, Jurassic magmatism and tectonism associated with Gondwanaland break-up: an Antarctic perspective. In: Storey, B.C., Alabaster, T., Pankhurst, R.J. (Eds.), Magmatism and the Causes of Continental Break-up. Geol. Soc. Special Pub. 68, pp. 165-184.

Elliot, D.H., 1996. The Hanson Formation: a new stratigraphical unit in the Transantarctic Mountains, Antarctica. Antarctic Sci. 8, 389-394.

Elliot, D.H., 2000. Stratigraphy of Jurassic pyroclastic rocks in the Transantarctic Mountains. J. African Earth Sci. 31, 7789.

Elliot, D.H., Hanson, R.E., 2001. Origin of widespread, exceptionally thick basaltic phreatomagmatic tuff breccia in the Middle Jurassic Prebble and Mawson Formations, Antarctica. J. Volcanol. Geotherm. Res. 111, 183-201.

Elliot, D.H., Siders, M.A., Haban, M.A., 1986a, Jurassic tholeiites in the region of the upper Rennick Glacier, North Victoria Land. In: Stump, E. (Ed.), Geological Investigations in Northern Victoria Land. Antarctic Res. Ser. 46, pp. 249-265.

Elliot, D.H., Haban, M.A., Siders, M.A., 1986b, The Exposure Hill Formation, Mesa Range. In: Stump, E. (Ed.), Geological Investigations in Northern Victoria Land. Antarcic Res. Ser. 46, pp. 267-278.

Elliot, D.H., Fleming, T.H., Kyle, P.R., Foland, K.A., 1999. Long-distance transport of magmas in the Jurassic Ferrar Large Igneous Province, Antarctica. Earth Planet. Sci. Lett. 167, 89-104.

Elliot, D.H., Fortner, T., Elliot, J.A.F., 2003. Mawson Formation at Allan Hills, Antarctica: evidence for a largescale phreatomagmatic caldera [abstract]. Eos 84(46), Fall Meet. Suppl., Abstract V52G-02.

Elliot, D.H., Fortner, T., Grimes, C.B., 2004. Beacon-Mawson field relations at Allan and Coombs Hills, south Victoria Land. In: Hubberten, H.-W. (Editor), Proceedings of the ninth international symposium on Antarctic earth sciences, Postdam (Germany). 
Ferris, J., Johnson, A., Storey, B., 1998. Form and extent of the Dufek intrusion, Antarctica, from newly compiled aeromagnetic data. Earth Planet. Sci. Lett. 154, 185-202.

Fisher, R.V., Schmincke, H.-U., 1984. Pyroclastic Rocks. Springer-Verlag, Berlin, 472 pp.

Fleming, T.H., Heimann, A., Foland, K.A., Elliot, D.H., 1997. ${ }^{40} \mathrm{Ar} /{ }^{39} \mathrm{Ar}$ geochronology of Ferrar Dolerite sills from the Transantarctic Mountains, Antarctica: Implications for the age and origin of the Ferrar magmatic province. Geol. Soc. Am. Bull. 109, 533-546.

Ford, A.B., Himmelberg, G.R., 1991, Geology and crystallization of the Dufek intrusion. In: Tingey, R.J. (Ed.), The Geology of Antarctica. Oxford Monogr. Geol. Geophys. 17, pp. 175-214.

Grapes, R.H., Reid, D.L., McPherson, J.G., 1974. Shallow dolerite intrusion and phreatic eruption in the Allan Hills region, Antarctica. N. Z. J. Geol. Geophys. 17, 563-577.

Grindley, G.W., 1963. The geology of the Queen Alexandra Range, Beardmore Glacier, Ross Dependency, Antarctica; with notes on the correlation of Gondwana sequences. N. Z. J. Geol. Geophys. 6, 307-347.

Gunn, B.M., Warren, G., 1962. Geology of Victoria Land between the Mawson and Murlock Glaciers, Antarctica. N. Z. Geol. Soc. Bull. 71, 157 pp.

Hanson, R.E., Elliot, D.H., 1996. Rift-related Jurassic phreatomagmatism in the central Transantarctic Mountains: precursory stage to flood-basalt effusion. Bull. Volcanol. 58, 327-347.

Hanson, R.E., Hargrove, U.S., 1999. Processes of magma/wet sediment interaction in a large-scale Jurassic andesitic peperite complex, northern Sierra Nevada, California. Bull. Volcanol. 60, 610-626.

Heiken, G., Wohletz, K., 1991, Fragmentation processes in explosive volcanic eruptions. In: Fisher, R.V., Smith, G.A. (Eds.), Sedimentation in volcanic settings. Soc. Econ. Paleontol. Mineralog. Special Pub. 45, pp. 19-26.

Hergt, J.M., Brauns, C.M., 2001. On the origin of Tasmanian Dolerites. Austr. J. Earth Sci. 48, 543-549.

Houghton, B., Wilson, C.J.N., 1989. A vesicularity index for pyroclastic deposits. Bull. Volcanol. 51, 451-462.

Houghton, B.F., Smith, R.T., 1993. Recycling of magmatic clasts during explosive eruptions: estimating the true juvenile content of phreatomagmatic volcanic deposits. Bull. Volcanol. 55, 414-420.

Houghton, B.F., Wilson, C.J.N., Rosenberg, M.D., Smith, I.E.M., Parker, R.J., 1996. Mixed deposits of complex magmatic and phreatomagmatic volcanism: an example from Crater Hill, Auckland, New Zealand. Bull. Volcanol. 58, 59-66.

Houghton, B.F., Wilson, C.J.N., Smith, I.E.M., 1999. Shallowseated controls on styles of explosive basaltic volcanism: a case study from New Zealand. J. Volcanol. Geotherm. Res. 91, 97-120.

Jackson, J.A., 1997. Glossary of Geology (fourth edition). American Geological Institute, Alexandria, Virginia, 769 pp.

Kokelaar, B.P., 1982. Fluidization of wet sediments during the emplacement and cooling of various igneous bodies. J. Geol. Soc. [London] 139, 21-33.

Kokelaar, B.P., 1983. The mechanism of Surtseyan volcanism. J. Geol. Soc. [London] 140, 939-944.

Korsch, R.J., 1984. The structure of Shapeless Mountain, Antarctica, and its relation to Jurassic igneous activity. N. Z. J. Geol. Geophys. 27, 487-504.
Kyle, P.R., Elliot, D.H., Sutter, J.F., 1981. Jurassic Ferrar Supergroup tholeiites from the Transantarctic Mountains, Antarctica, and their relationship to the initial fragmentation of Gondwana. In: Crosswell, M.M., Vella, P. (Eds.), Gondwana Five; selected papers and abstracts of papers presented at the Fifth International Gondwana Symposium, pp. 282-287.

Lorenz, V., 1974. Studies of the Surtsey tephra deposits. Surtsey Research Progress Report VII:72-79.

Lorenz, V., 1975. Formation of phreatomagmatic maardiatreme volcanoes and its relevance to kimberlite diatremes. Phys. Chem. Earth 9, 17-27.

McClintock, M.K., 2001. Phreatomagmatism at Coombs Hills, Antarctica - Magma-water super-volcanism in a wet, failed rift. M.Sc. Thesis, University of Otago, Dunedin, New Zealand.

McClintock, M.K., White, J.D.L., 2005. Large-volume phreatomagmatic vent complex at Coombs Hills, Antarctica records wet, explosive initiation of flood basalt volcanism in the Ferrar LIP. Bull. Volcanol. (in press).

McClintock, M.K., Houghton, B.F., Skilling, I.P., White, J.D.L., 2003. Evolution of a large-volume explosive ventcomplex at the base of the Karoo LIP: Sterkspruit Complex, South Africa [abstract]. Eos 84(46) (Fall meeting suppl.), Abstract V52G-05.

Mitchell, R.H., 1986. Kimberlites: mineralogy, geochemistry and petrology. Plenum Press, New York, 442 pp.

Moore, J.G., 1985. Structure and eruptive mechanisms at Surtsey Volcano, Iceland. Geol. Mag. 122, 649-661.

Morrissey, M., Zimanowski, B., Wohletz, K., Buettner, R., 2000. Phreatomagmatic fragmentation. In: Sigurdsson, H., Houghton, B., McNutt, S.R., Rymer, H., Stix, J. (Eds.), Encyclopedia of Volcanoes. Academic Press, London, pp. 431-445.

Mortimer, N., Parkinson, D., Raine, J.I., Adams, C.J., Graham, I.J., Oliver, P.J., Palmer, K., 1995. Ferrar magmatic province rocks discovered in New Zealand: Implications for Mesozoic Gondwana geology. Geology [Boulder] 23, $185-188$.

Raue, H., 2004. A new model for the fracture energy budget of phreatomagmatic explosions. J. Volcanol. Geotherm. Res. 129, 99-108.

Reubi, O., Ross, P.-S., White, J.D.L., 2005. Debris avalanche deposits associated with Large Igneous province volcanism: an example from the Mawson Formation, Central Allan Hills, Antarctica. Geol. Soc. Am. Bull. (in revision).

Ross, P.S., 2005. Volcanology of the Mawson Formation at Coombs and Allan Hills, South Victoria Land, Antarctica. $\mathrm{PhD}$ thesis, University of Otago, Dunedin, New Zealand, $400 \mathrm{pp}$.

Ross, P.-S., White, J.D.L., 2003. Discontinuous volcanic eruptions in a phreatomagmatic vent complex: Coombs Hills, South Victoria Land. Can. Antarc. Res. Network Newslett. 16, 4-6.

Ross, P.-S., White, J.D.L., 2005a. Mafic, large-volume, pyroclastic density current deposits from phreatomagmatic eruptions in the Ferrar large igneous province, Antarctica. J. Geol. (in revision).

Ross, P.-S., White, J.D.L., 2005b. Unusually large clastic dykes formed by elutriation of a poorly sorted, coarsergrained source. J. Geol. Soc. [London] 162, 579-582.

Ross, P.-S., Ukstins Peate, I., McClintock, M.K., Xu, Y.G., Skilling, I.P., White, J.D.L., Houghton, B.F., 2005. Mafic volcaniclastic deposits in flood basalt provinces: a review. 
J. Volcanol. Geotherm. Res., doi:10.1016/j.jvolgeores.2005.02.003

Rosseel, J.-B., White, J.D.L., Houghton, B.F., submitted. Complex bombs of an historical phreatomagmatic eruption: the role of agglomeration and welding in vents of the 1886 Rotomahana (Tarawera) eruption, New Zealand. J. Geophys. Res.

Siders, M.A., Elliot, D.H., 1985. Major and trace element geochemistry of the Kirkpatrick Basalt, Mesa Range, Antarctica. Earth Planet. Sci. Lett. 72, 54-64.

Skilling, I.P., White, J.D.L., McPhie, J., 2002. Peperite: a review of magma-sediment mingling. J. Volcanol. Geotherm. Res. 114, 1-17.

Stump, E., 1995. The Ross Orogen of the Transantarctic Mountains. Cambridge University Press, Cambridge, 284 pp.

Thorarinsson, S., Einarsson, T., Sigvaldason, G., Elisson, G., 1964. The submarine eruption off the Westmann Islands 1963-64. Bull. Volcanol. 27, 435-445.
Valentine, G.A., Groves, K.R., 1996. Entrainment of country rock during basaltic eruptions of the Lucero volcanic field, New Mexico. J. Geol. 104, 71-90.

White, J.D.L., 1996. Pre-emergent construction of a lacustrine basaltic volcano, Pahvant Butte, Utah. Bull. Volcanol. 58, 249-262.

White, J.D.L., McClintock, M.K., 2001. Immense vent complex marks flood-basalt eruption in a wet, failed rift: Coombs Hills, Antarctica. Geology [Boulder] 29, 935938.

White, J.D.L., McPhie, J., Skilling, I.P., 2000. Peperite: a useful genetic term. Bull. Volcanol. 62, 65-66.

Wohletz, K.H., 1983. Mechanisms of hydrovolcanic pyroclast formation: grain-size, scanning electron microscopy, and experimental studies. J. Volcanol. Geotherm. Res. 17, 3163.

Table 1

Surface area occupied by the most abundant rock facies in the field area at Coombs Hills ${ }^{(a)}$

\begin{tabular}{|c|c|c|c|c|}
\hline \multirow[b]{2}{*}{ Facies } & \multicolumn{2}{|c|}{ Facies codes } & \multirow{2}{*}{$\begin{array}{c}\text { Area } \\
\left(\mathrm{x} 10^{3} \mathrm{~m}^{2}\right)\end{array}$} & \multirow[b]{2}{*}{$\%$ total } \\
\hline & This study & $\begin{array}{l}\text { M. \& W. } \\
(2005)^{(b)}\end{array}$ & & \\
\hline \multicolumn{5}{|l|}{$\begin{array}{l}\text { Non-bedded, poorly sorted volcaniclastic } \\
\text { deposits }\end{array}$} \\
\hline Heterolithologic lapilli-tuff & $\mathrm{LT}_{\mathrm{h}}$ & $\mathrm{TB}_{\mathrm{u}}$ & 1335.0 & 60.4 \\
\hline Basalt-rich tuff-breccia or lapilli-tuff & $\mathrm{TB}_{\mathrm{j}}$ & $\mathrm{TB} 0_{\mathrm{j}}$ & 417.7 & 18.9 \\
\hline Other lapilli-tuff (map A only) & $\mathrm{LT}_{\mathrm{o}}$ & - & 43.6 & 2.0 \\
\hline "Raggy" heterolithologic tuff-breccia & $\mathrm{TB}_{\mathrm{hr}}$ & - & 33.3 & 1.5 \\
\hline Beacon-rich lapilli-tuff or tuff-breccia & $\mathrm{LT}_{\mathrm{a}}$ & $\mathrm{TB} 0_{1}$ & $-(c)$ & $-(\mathrm{c})$ \\
\hline \multicolumn{5}{|l|}{ Bedded volcaniclastic deposits } \\
\hline Pyramid sequence & - & various & 214.9 & 9.7 \\
\hline Tuff ring-style deposits & - & - & 21.3 & 1.0 \\
\hline \multicolumn{5}{|l|}{ Igneous and clastic intrusions } \\
\hline Basalt plugs & - & - & 68.5 & 3.1 \\
\hline Volcaniclastic dikes & - & - & 35.9 & 1.6 \\
\hline \multicolumn{5}{|l|}{ Other facies } \\
\hline Other facies, combined & - & - & 39.1 & 1.8 \\
\hline TOTAL & & & 2209.3 & 100.0 \\
\hline
\end{tabular}

(a) The extent of the mapped area is shown on Figs 1d and 2. Surface area figures were calculated without interpolating between outcrops (i.e., across large patches of scree or snow) and represent relatively large rock domains (10s of $\mathrm{m}$ across or more), which excludes most of the $\mathrm{LT}_{\mathrm{a}}$ zones, some $\mathrm{TB}_{\mathrm{j}}$ zones, most "rafts", many volcaniclastic dikes, and many basalt dikes. Calculations exclude large sedimentary rafts outside the Mawson Formation (NE corner of field area), which occupy at least $55.4 \times 10^{3} \mathrm{~m}^{2}$.

(b) McClintock and White (2005).

(c) The largest $\mathrm{LT}_{\mathrm{a}}$ zones are included in the figures for "other facies", but the smaller ones are not accounted for in these calculations because they were to small to plot on Fig. 2. The overall abundance of this facies in the field area is estimated to $<1 \%$. 
Table 2

Facies descriptions and interpretations for some of the non-bedded, poorly sorted rocks in the Mawson Formation north of Mt Brooke at Coombs Hills (see text for $\mathrm{LT}_{\mathrm{a}}$ and $\mathrm{TB}_{\mathrm{j}}$ zones

\begin{tabular}{|c|c|c|}
\hline Facies (code) & Observations & Inter pretations \\
\hline $\begin{array}{l}\text { Heterolithologic } \\
\text { lapilli-tuff }\left(\mathrm{LT}_{\mathrm{h}}\right)\end{array}$ & $\begin{array}{l}\text { 1- volumetrically dominant facies, } 60 \% \text { of field area (locally a tuff-breccia) } \\
\text { 2- lacks bedding planes \& consistent clast alignments for }>300 \text { vertical metres } \\
\text { 3- lateral variations in grainsize \& componentry are observed, but no systematic vertical } \\
\text { variations } \\
\text { 4- consists of glassy } \\
\text { particles, Beacon sedimentary y rock fragments, composite (recycled peperite) clasts \& } \\
\text { rare granite fragments; blocks can reach several m in size } \\
\text { 5- basaltic clasts are variably vesicular, most being dense to incipiently vesicular } \\
\text { (vesicularity index of Houghton \& Wilson, } 1989 \text { ); basaltic fragments display wide } \\
\text { range of vesicularity in single hand samples or thin sections; vesicle shapes vary } \\
\text { from spherical to very elongate } \\
\text { 6- host for } \mathrm{LT}_{a} \& \mathrm{~TB}_{\text {; }} \text { zones; cross-cut by volcaniclastic dikes (see Ross \& White, } \\
\text { 2005b), basaltic dikes \& basalt plugs (e.g., Figs. } 3 \& 4 \text { ) } \\
\text { 7- hosts steeply dipping rafts (fragments }>2 \text { m across), described in Table } 3\end{array}$ & $\begin{array}{l}\text { - observations 4-5 indicate that country rock was extensively fragmented; that magma cooled } \\
\text { rapidly \& was fractured in the brittle regime; and that it was disrupted at different points of } \\
\text { its degassing history (generally early), under a range of strain/decompression rates - together } \\
\text { these features are the hallmark of phreatomagmatic fragmentation (e.g., Wohletz, 1983; } \\
\text { Fisher \& Schmincke, 1984; Barberi et al., 1989; Houghton \& Wilson, 1989; Heiken \& } \\
\text { Wohletz, 1991; Houghton et al., 1996, 1999; White, 1996; Morrissey et al., 2000) } \\
\text { - an origin as one or several lahars (Hanson \& Elliot, 2001) or subaerial pyroclastic flows } \\
\text { (hinted at by Bradshaw, 1987) filling a pre-existing topographic depression (cf. Allan Hills, } \\
\text { see Ross \& White 2005a) is not favoured because of observations 2,3 \& } 7 \text { (steeply dipping } \\
\text { rafts are typical of diatremes, e.g. Lorenz, 1975; Mitchell, 1986; White \& McClintock, 2001) } \\
\text { (b) } \\
\text { - emplacement in a vent complex (McClintock \& White, 2005); much of the debris now } \\
\text { exposed never reached the surface, or at least fell back into vents after ejection (c) } \\
\text { - several cycles of eruption probably necessary to reach proportions of glassy basalt clasts } \\
\text { observed in } \mathrm{LT}_{\mathrm{h}}\end{array}$ \\
\hline $\begin{array}{l}\text { Other lapilli-tuff } \\
\left(\mathrm{LT}_{\mathrm{o}}\right)\end{array}$ & $\begin{array}{l}\text { - local host rock in Map A (not seen elsewhere) } \\
\text { - somewhat finer \& more B eacon-rich than most } \mathrm{LT}_{\mathrm{h}} \text { outcrops, but does not contain as } \\
\text { many Beacon lapilli \& blocks as } \mathrm{LT}_{\mathrm{a}} \text { (Fig. 5) }\end{array}$ & - vent complex setting, local variant of $\mathrm{LT}_{\mathrm{h}}$ \\
\hline $\begin{array}{l}\text { "Raggy" } \\
\text { heterolithologic } \\
\text { tuff-breccia }\left(\mathrm{TB}_{\mathrm{hr}}\right)\end{array}$ & $\begin{array}{l}\text { - volumetrically minor, gradational contacts w/ } \mathrm{LT}_{\mathrm{h}} \text { (over several metres) } \\
\text { - tuff-breccia version of } \mathrm{LT}_{\mathrm{h}} \mathrm{w} / \text { abundant "rags" (15-50\%) } \\
\text { - "ragg" = relatively vesicular, glassy basaltic fragments, elongate, up to several dm long, } \\
\text { w/ bended shapes, delicate ends forming spiral shapes \& displaying accommodation of } \\
\text { surrounding clasts } \\
\text { - "rags" can be aligned in any orientation or be 'randomly' disper sed; alignments are } \\
\text { inconsistent between outcrops, e.g., the outcrop next to one displaying sub-horizontally } \\
\text { aligned "rags" may show nearly random "rag" orientation, although these outcrops } \\
\text { might be at the same topographic level \& relatively close laterally }\end{array}$ & $\begin{array}{l}\text { - "rags" tran sported while still plastic (high temperature) } \\
\text { - } \mathrm{LT}_{\mathrm{h}} \text {-type material simultaneously transported w/ "rags" was probably cool (quenched, blocky } \\
\text { basalt clasts \& Beacon material) } \\
\text { - zones containing 'randomly' or sub-vertically aligned "rags" could have formed when } \\
\text { phreatomagmatic explosions accelerated vesiculating melt not directly involved in the } \\
\text { explosions } \\
\text { - zones containing sub-horizontally aligned "rags" are difficult to explain }\end{array}$ \\
\hline
\end{tabular}

\footnotetext{
(a) "Glassy" basaltic glass are now altered to palagonite \& clays; no fresh sideromelane remains.

(b) In southern Allan Hills, high-concentration pyroclastic density currents deposited poorly sorted, internally structureless thick layers w/ a componentry similar to $\mathrm{LT}_{\mathrm{h}}, \mathrm{LT}_{\mathrm{a}}$ or $\mathrm{TB}_{\mathrm{j}}(\mathrm{Ross} \& \mathrm{White,}, 2005 \mathrm{a})$ Contacts between these sub-horizontal layers can be gradational, but some are sharp \& abrupt variations in grain size \& componentry exist in vertical sections. This is because the particle size \& clast composition of successive density currents changed w/ time. The thickest layer is about $15 \mathrm{~m}$ thick. Given these observations, it would be surprising if similar processes had produced either a single $>300 \mathrm{~m}$
thick $\mathrm{LT}_{\mathrm{h}}$ deposit, or successive layers w/ exactly the same grain size \& $\mathrm{LT}$ composition, at Coombs Hills. thick $\mathrm{T}_{\mathrm{h}} \mathrm{deposit,}$, socs

(c) Elliot \& Hanson (2001) dismissed the phreatocauldron concept of White \& McClintock (2001) on the basis of observations of Mawson-B eacon-contacts SE of Mt Brooke. Elliot et al. (2003, 2004), however, revisited this area \& now describe this contact as "complex", probably "intrusive"; they infer that it represents a "collapse structure" such as a caldera margin. Elliot et al. (2004) describe the "more than $360 \mathrm{~m}$ of unbedded tuff breccia" at Otway Massif (Central Transantarctic Mountains, Fig. 1a) as also filling a "collapse structure"; this appears to be a significant modification of the Elliot \& Hanson (2001) laharic model for Coombs Hills, Allan Hills \& Otway Massif.
} 
Table 3

Characteristics of rafts "floating" in the non-bedded, poorly sorted volcaniclastic rocks at Coombs Hills

$\begin{array}{ccc}\text { Raft type } & \text { Field characteristics } & \begin{array}{c}\text { Composition \& petrographic } \\ \text { characteristics }\end{array}\end{array}$

\begin{tabular}{|c|c|c|}
\hline "Yellow" rafts & $\begin{array}{l}\text { - abound near eastern Mawson Formation-Beacon Supergroup contact (only a } \\
\text { few of these shown on Fig. 2); generally density of rafts increases toward } \\
\text { contact (McClintock, 2001); in contact area, rafts may reach } 100 \mathrm{~s} \text { of } \mathrm{m} \text { in } \\
\text { max. horizontal dimension \& commonly have a sub-horizontal stratification } \\
\text { plane; often long axis of rafts runs } \sim \mathrm{N}-\mathrm{S} \text {, parallel to Mawson-Beacon contact } \\
\text { - } \text { rafts of smaller size }(2 \mathrm{~m} \text { to } 10 \mathrm{~s} \text { of } \mathrm{m} \text { ) present in isolated clusters of } \sim 3-10 \\
\text { rafts within facies } \mathrm{LT}_{\mathrm{h}} \text { on East Ridge (e.g., map C) \& as individual bodies } \\
\text { separated by several } 100 \mathrm{~s} \text { of m or more elsewhere in facies } \mathrm{LT}_{\mathrm{h}} \text { or } \mathrm{TB}_{\mathrm{j}} \\
\text { - } \text { rafts are generally stratified; dip magnitude of strata for } 5 \text { map C rafts varies } \\
\text { from } 20 \text { to } 70^{\circ} \text { (data plotted on Fig. } 4 \text { ), w/ no preferential orientation of dip } \\
\text { directions } \\
\text { in some of the smaller rafts, layering has been disrupted to various degrees, } \\
\text { ranging from local distortion to total obliteration }\end{array}$ & $\begin{array}{l}\text { cream-beige to yellowish, } \\
\text { very fine to coarse-grained } \\
\text { material visually } \\
\text { resembling yellowish, } \\
\text { impure Lashly Formation } \\
\text { sandstones observed in situ } \\
\text { at Allan Hills (Ross, 2005) } \\
\text { - } \text { some rafts contain abundant } \\
\text { formerly glassy silicic } \\
\text { shards (now altered to } \\
\text { zeolites), whereas others } \\
\text { lack them totally (they are } \\
\text { "normal" sandstones) }\end{array}$ \\
\hline
\end{tabular}


Table 4

Origin of type (2) $\mathrm{TB}_{\mathrm{j}}$ zones north of Mt Brooke at Coombs Hills *

\begin{tabular}{|c|c|}
\hline Topic & Discussion \\
\hline $\begin{array}{l}\text { General } \\
\text { remarks }\end{array}$ & $\begin{array}{l}\text { - common lack of blocky basaltic clasts, greater relative abundance of rounded quartz grains (as opposed to } \\
\text { angular quartz), gradational contacts } \mathrm{w} / \text { host in places, or complex boundaries where contacts are sharper, } \\
\text { suggest less violent origin than that of } \mathrm{LT}_{\mathrm{a}} \text { pipes or type (1) } \mathrm{TB}_{\mathrm{j}} \text { zones } \\
\text { - ubiquitous spatial association of these zones w/ domains of unfragmented (coherent) basalt \& in situ peperite } \\
\text { suggests a genetic relationship }\end{array}$ \\
\hline $\begin{array}{l}\text { Peperite \& its } \\
\text { importance }\end{array}$ & $\begin{array}{l}\text { - basaltic clasts in } \mathrm{TB}_{\mathrm{j}} \text { immediately adjacent to in situ peperite domains seem to have been partly sourced from } \\
\text { peperite, which itself has derived them from pods of coherent basalt } \\
\text { - basalt pods and surrounding peperites are an integral part of the } \mathrm{TB}_{\mathrm{j}} \text { facies, rather than younger, unrelated, } \\
\text { cross-cutting intrusions }\end{array}$ \\
\hline $\begin{array}{l}\text { Juvenile clast- } \\
\text { forming } \\
\text { processes }\end{array}$ & $\begin{array}{l}\text { juvenile clast-forming processes in peperite include (a) magma quenching \& autobrecciation (mechanical } \\
\text { stress), (b) steam explosions due to external water, (c) violent magma vesiculation, (d) shearing of magma } \\
\text { during movement of pore water \& fluidised sediment, (e) surface tension effects, (f) magma-sediment density } \\
\text { contrasts, and (g) instabilities in vapour films (Skilling et al., 2002) [In the present context, the 'sediment' } \\
\text { (granular host) consists of existing coarse volcaniclastic material] } \\
\text { - both fluidal \& blocky peperite (Busby-Spera \& White, 1987), w/ variable clast size \& dispersion from coherent } \\
\text { source, was observed at Coombs Hills, so most of these fragmentation processes appear plausible }\end{array}$ \\
\hline $\begin{array}{l}\text { Mingling of } \\
\text { juvenile clasts }\end{array}$ & $\begin{array}{l}\text { mingling of existing 'sediment' (volcaniclastic debris) w/ newly-formed juvenile clasts has been attributed to } \\
\text { various processes in the literature, including fluidisation of host (Kokelaar, 1982), forceful intrusion of magma, } \\
\text { phreatomagmatic explosions (Busby-Spera \& White, 1987; Hanson and Hargrove, 1999) \& magma-host density } \\
\text { contrasts (Skilling et al., 2002) } \\
\text { - authors are unable to isolate a single mingling process as being the most relevant for Coombs Hills, as all appear } \\
\text { plausible }\end{array}$ \\
\hline
\end{tabular}

* See text for description of these zones

Table 5

End-member possibilities for the behaviour of debris jets travelling through a granular host (see Fig. 11 for illustration)

\begin{tabular}{|c|c|c|c|c|c|c|}
\hline Feature $\downarrow \quad$ case number $\rightarrow$ & 1.1 & 1.2 & 2.1 & 2.2 & 3.1 & 3.2 \\
\hline Relatively dense or dilute jet & Dense & Dilute & Dense & Dilute & Dense & Dilute \\
\hline $\begin{array}{l}\text { Jet erodes host by upward displacement of } \\
\text { material }\end{array}$ & Yes $^{(a)}$ & $\mathrm{Yes}^{(\mathrm{b})}$ & - & - & - & - \\
\hline $\begin{array}{l}\text { Jet erodes host by entrainment/ abrasion \& } \\
\text { mixing of debris }\end{array}$ & - & - & Yes & Yes & - & - \\
\hline $\begin{array}{l}\text { Shallow host deforms laterally to let jet pass } \\
\text { without erosion and rebounds afterwards }\end{array}$ & - & - & - & - & Yes & Yes \\
\hline $\begin{array}{l}\text { Conduit collapse when jet stops moving \& } \\
\text { gas/vapour escapes or condenses }\end{array}$ & Small & $\begin{array}{l}\text { Signi- } \\
\text { ficant }\end{array}$ & Small & $\begin{array}{l}\text { Signi- } \\
\text { ficant }\end{array}$ & $\begin{array}{l}\text { Insigni- } \\
\text { ficant }\end{array}$ & Minor \\
\hline
\end{tabular}

${ }^{\text {(a) }}$ Extrusion of host material at surface.

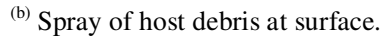




\section{Figures}

1. (a) Map showing the distribution of the Beacon Supergroup, Ferrar Dolerite, and Kirkpatrick Basalt in the Transantarctic Mountains (TAM). Mafic volcaniclastic deposits, including the Mawson Formation, are found underlying the Kirkpatrick Basalt in North Victoria Land (NVL), South Victoria Land (SVL) and the Central Transantarctic Mountains (CTM). Redrawn after Hanson and Elliot (1996). (b) Summary stratigraphic sections of the Ferrar Group showing flood lavas and mafic volcaniclastics (thicknesses after Elliot, 2000). (c) Hypothetical former distribution of the Mawson Formation, interpolating between known occurrences. The illustrated belt is $\sim 195 \mathrm{~km}$ long, with a mean width of $\sim 21 \mathrm{~km}$. Exposed thicknesses are generally over $60 \mathrm{~m}$. Base map modified from Stump (1995). (d) Map of Coombs Hills showing the outcrop distribution of the Mawson Formation (shaded; includes interpolation between outcrops; modified from McClintock, 2001), the inferred approximate limits of the vent complex (heavy dashed line), and the limits of the field area (thinner dashed line). The location of detailed maps $\mathrm{A}$ and $\mathrm{C}$ is shown by small boxes.

2. Simplified geology of the mapped outcrops in the field area (dashed outline) at Coombs Hills. Non-bedded Mawson deposits are divided into lithofacies based on grain size and componentry (see Tables 1 and 2 for details). Beacon rafts outside the Mawson Formation (NE corner of map) are hosted by basaltic intrusions. The location of detailed maps A and $\mathrm{C}$ is shown by boxes. The names 'East Ridge', 'West Ridge', 'Windy Ridge' and 'Central Valley' are informal.

3. Detailed map of a small sector in the western portion of the field area ("map A"). This illustration and map C were prepared based on some 1500 survey points (total) acquired with a laser range finder coupled with an electronic compass mounted on a tripod. In map A, no rafts or volcaniclastic dikes are present. Abundant cross-cutting LT $_{\mathrm{a}}$ zones are relatively small and compact (except for the large, incompletely mapped one), whereas peperite \& $\mathrm{TB}_{\mathrm{j}}$ zones are larger and more complex. The host for these zones is $\mathrm{LT}_{\mathrm{o}}$ rather than $\mathrm{LT}_{\mathrm{h}}$ as observed everywhere else. See Fig. 2 for map location and Tables 1 and 2 for explanation of facies codes.

4. Detailed map of a small area on the East Ridge ("map C") showing the size, shape and distribution of rafts (Beacon sandstone, silicic tuff, volcaniclastic), dikes (volcaniclastic, basaltic), and cross-cutting zones $\left(\mathrm{TB}_{\mathrm{j}}\right.$, $\mathrm{LT}_{\mathrm{a}}$ ) in the Mawson Formation. See Fig. 2 for location and Tables 1 and 2 for explanation of facies codes.

5. Summary of field clast counts for facies $\mathrm{LT}_{\mathrm{h}}, \mathrm{LT}_{\mathrm{a}}, \mathrm{TB}_{\mathrm{j}}$, and $\mathrm{LT}_{\mathrm{o}}$. The clast counts were executed by unrolling a $1 \mathrm{~m}^{2}$ net on representative surfaces; the net has grid indicators every $10 \mathrm{~cm}$ in both directions (i.e., there are over 100 grid indicators), and clasts under each one were counted into componentry categories. Blocks and bombs (verified to be $>64 \mathrm{~mm}$ across with a tape measure) were counted in separate categories from lapilli and ash-grade particles in order to get the total proportions of the main clast sizes, as well as the componentry. Columns on the graphs represent the mean of $n$ counts; the error bars show one standard deviation from the mean, and the numbers near the labels give minimum and maximum values. The top row of graphs shows the whole rock grainsize whereas the bottom row displays the componentry of the combined block and lapilli fractions. Overall, $\mathrm{TB}_{\mathrm{j}}$ rocks at Coombs Hills seem to be dominantly tuff-breccias (visual examination), but all five clasts counts sampled lapilli-tuffs. No field clast counts are available for facies $\mathrm{TB}_{\mathrm{hr}}$.

6. Plane-polarized, transmitted light photomicrographs of non-bedded volcaniclastic deposits in the Mawson Formation, showing the main components of the ash fraction: quartz $(\mathbf{Q})$, sandstone or siltstone $(\mathbf{S})$, dense to incipiently vesicular, formerly glassy basalt $(\mathbf{B})$, and rare vesicular basalt $\left(\mathbf{B}_{\mathbf{V}}\right)$. Rock in photo (b) has a zeolite cement, and very little fine ash, whereas no cement in visible in (a) at this scale but more optically irresolvable material is present. Also note, in (a), the engulfed detrital quartz crystal in a basaltic clast (marked by a dashed white line).

7. Petrographic compositional point-counting data (over 400 points per sample) for non-bedded volcaniclastic deposits. The upper-right diagram shows the proportion of resolvable ash relative to cement, irresolvable material and lapillisized fragments, whereas the other three diagrams display the componentry of the resolvable ash fraction only. "Other detrital" includes micas, feldspars, chlorite, opaque minerals, and rare garnet. Basaltic clasts with either 0-10\% vesicles or $>10 \%$ vesicles are formerly glassy (now altered to clay and palagonite), free of microlites or phenocrysts, and free of xenocrysts. "Other basalt" includes fragments with microlites or xenocrysts.

8. Shape analysis for rafts and cross-cutting zones in the Mawson Formation. (a) Anisometry values for five ellipses, given for reference. (b) Shape factors for some mathematical and natural objects, given for reference. (c) Shape factor plotted against anisometry for all surveyed geological objects for which the complete perimeter was available. Sandstone rafts and "silicic tuff" rafts on the figure together correspond to "yellow rafts" in Table 3. Anisometry is the ratio of the minor and major axes of the best-fitting ellipse for each object, and indicates the extent to which objects are elongate (small values) or equant in shape (anisometry approaching 1.0, the value for a perfect circle or a square). Shape factors were calculated using $S F=4 \pi A / p^{2}$, where $A$ is the surface area of each object and $p$ the perimeter. A circle has a shape factor of 1.0 and every other object has a smaller shape factor; how much smaller depends on both the elongation of the object (also affecting the anisometry) and the irregularity or tortuosity of the perimeter. 
9. Photographs of cross-cutting lapilli-tuff and tuff-breccia zones in the Mawson Formation: (a) $\mathrm{LT}_{\mathrm{a}}$ zone invading $\mathrm{LT}_{\mathrm{h}}$ in southern map $\mathrm{C}$ (sub-circular depression under standing person; this is the zone nearest to the wide volcaniclastic dike on Fig. 4); (b) $\mathrm{TB}_{\mathrm{j}}$ \& peperite zone with steep to sub-vertical contacts (under hammer) invading $\mathrm{LT}_{\mathrm{o}}$ in southern map A.

10. Sketch (vertical cross-section) of an established Beacon-rich debris jet passing through existing non-consolidated vent-filling material $\left(\mathrm{LT}_{\mathrm{h}}\right)$ at Coombs Hills. Very little material it entrained from the walls of the conduit at this stage, so that the jet (and the future $\mathrm{LT}_{\mathrm{a}}$ pipe) is laterally uniform in composition and sharply different in composition from the host. The velocity profile for laminar flow may or may not be applicable to such a jet. See text for explanation.

11. Series of sketches showing end-member possibilities for the behaviour of debris jets travelling through a relatively dry, non-fluidised granular host. Phreatomagmatic explosions deeper down (not shown) produced these jets at Coombs Hills. Unfilled circles represent granular material from the shallow host, whereas filled circles represent material which was included in the jet below the level shown in the cartoons. For the Coombs Hills situation, deep-sourced material could include new juvenile particles from magma fragmentation and chilling, existing volcaniclastic debris, and possibly new accidental debris from the walls or floor of the vent complex. See text and Table 5 for explanation of the different end-member cases. 
a

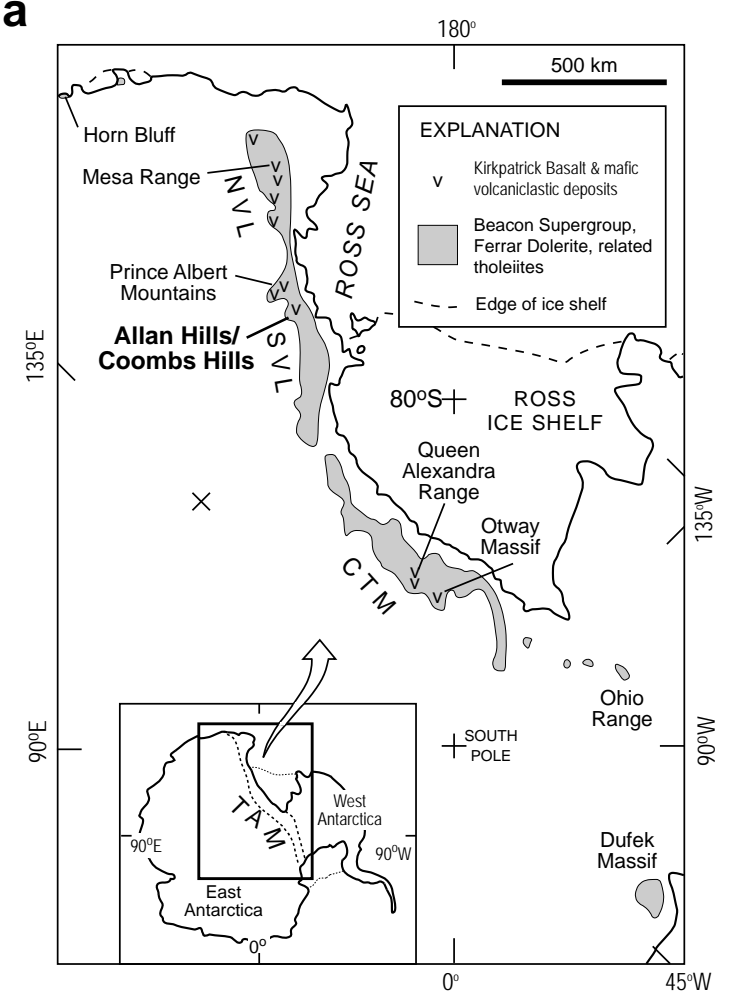

b

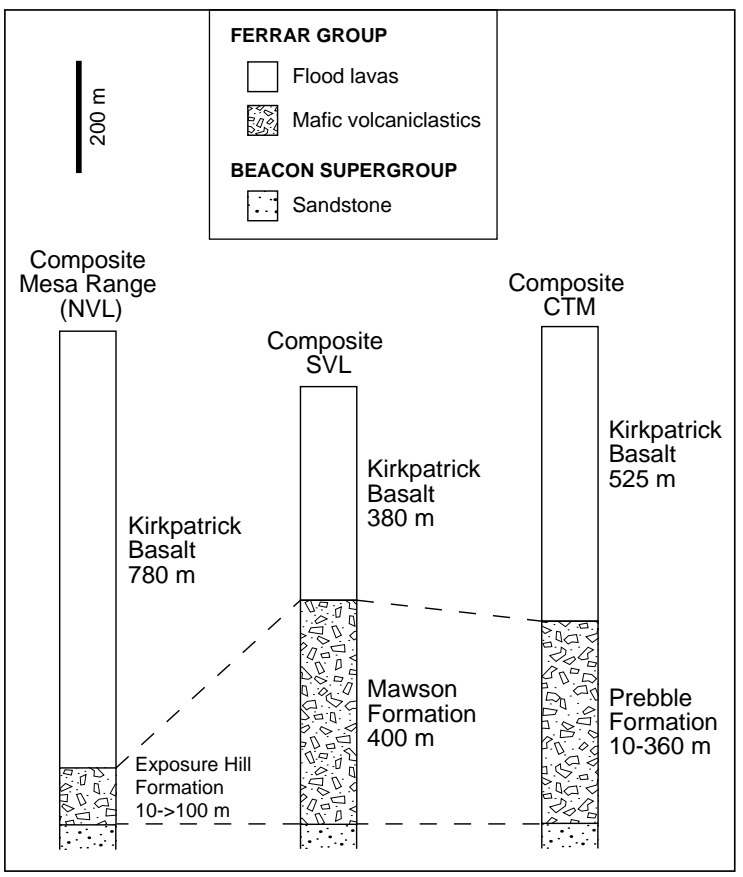

C

Hypoth. former distribution of Mawson Fm

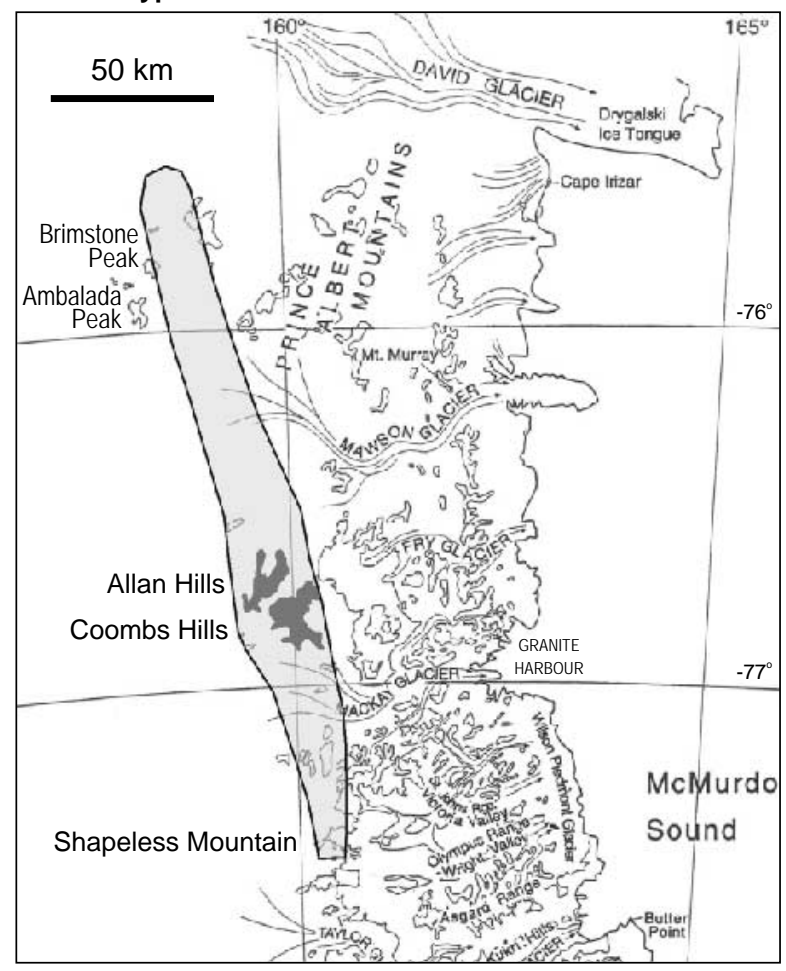

d

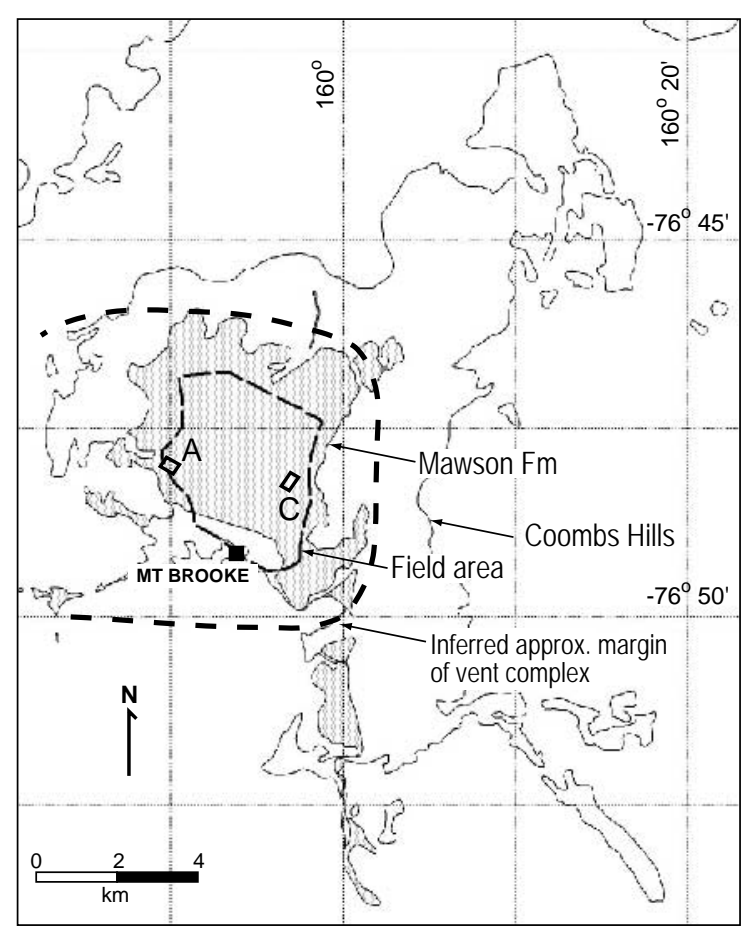

ROSS AND WHITE, COOMBS HILLS, FIG. 1 


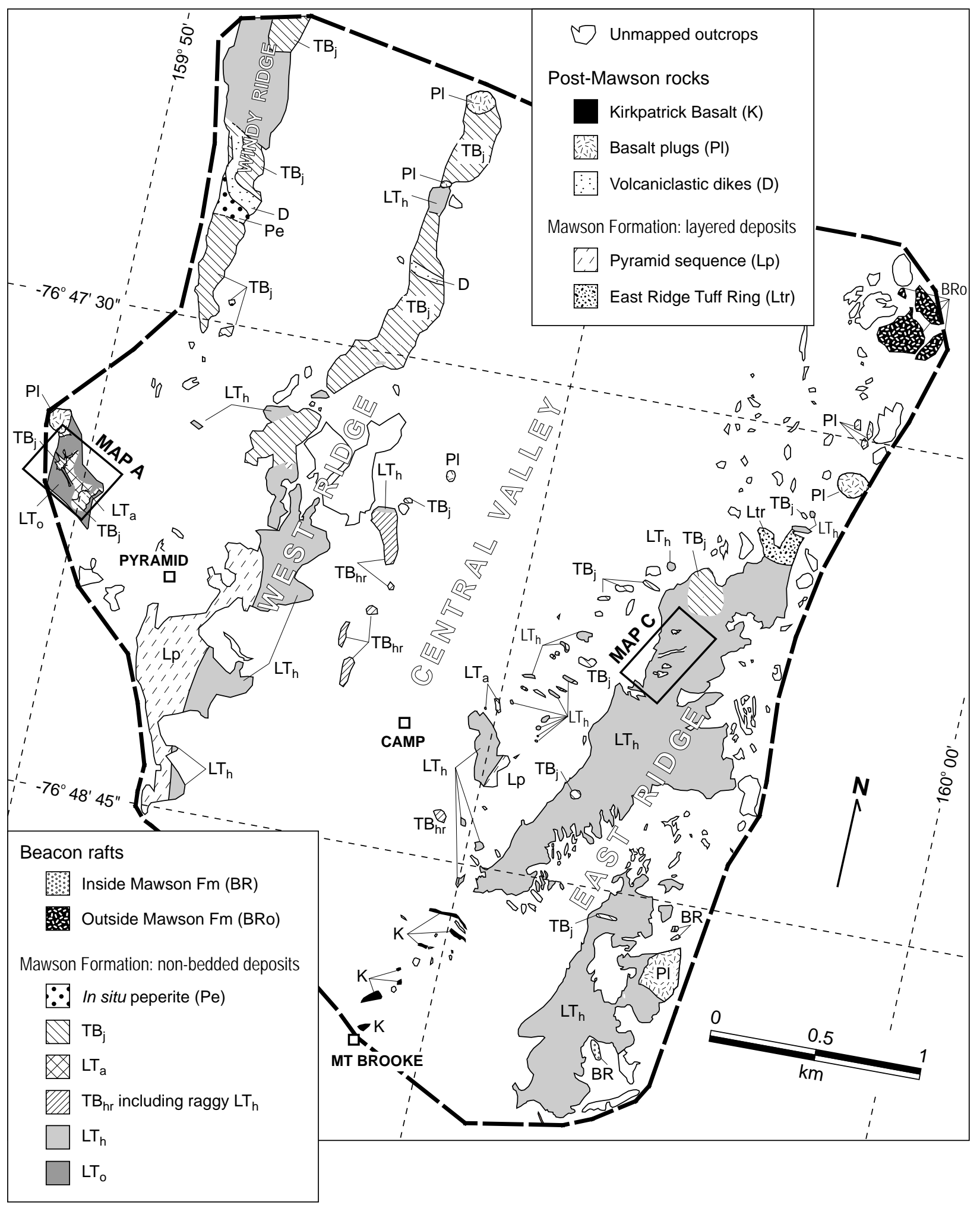

ROSS AND WHITE, COOMBS HILLS, FIG. 2 


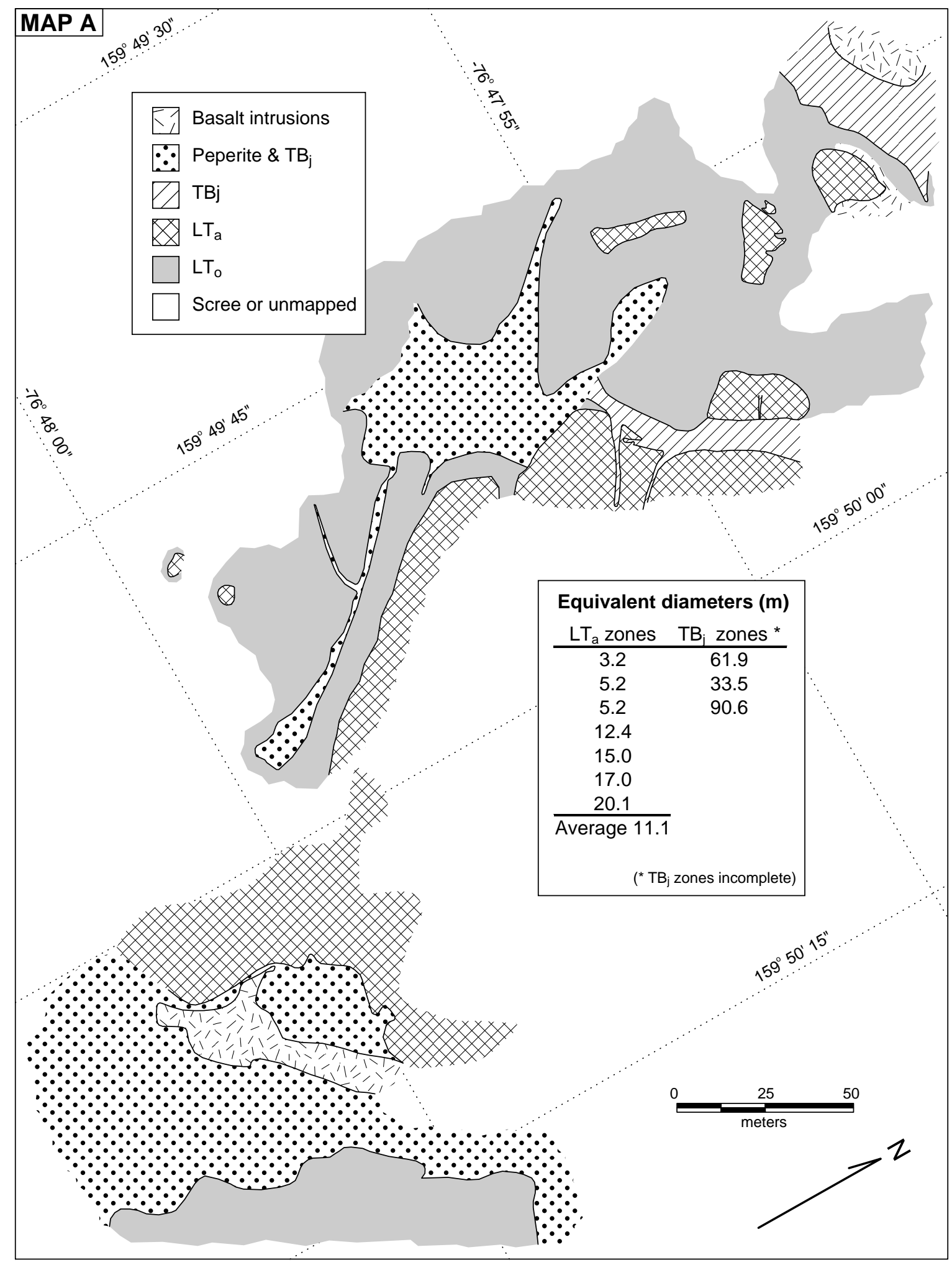




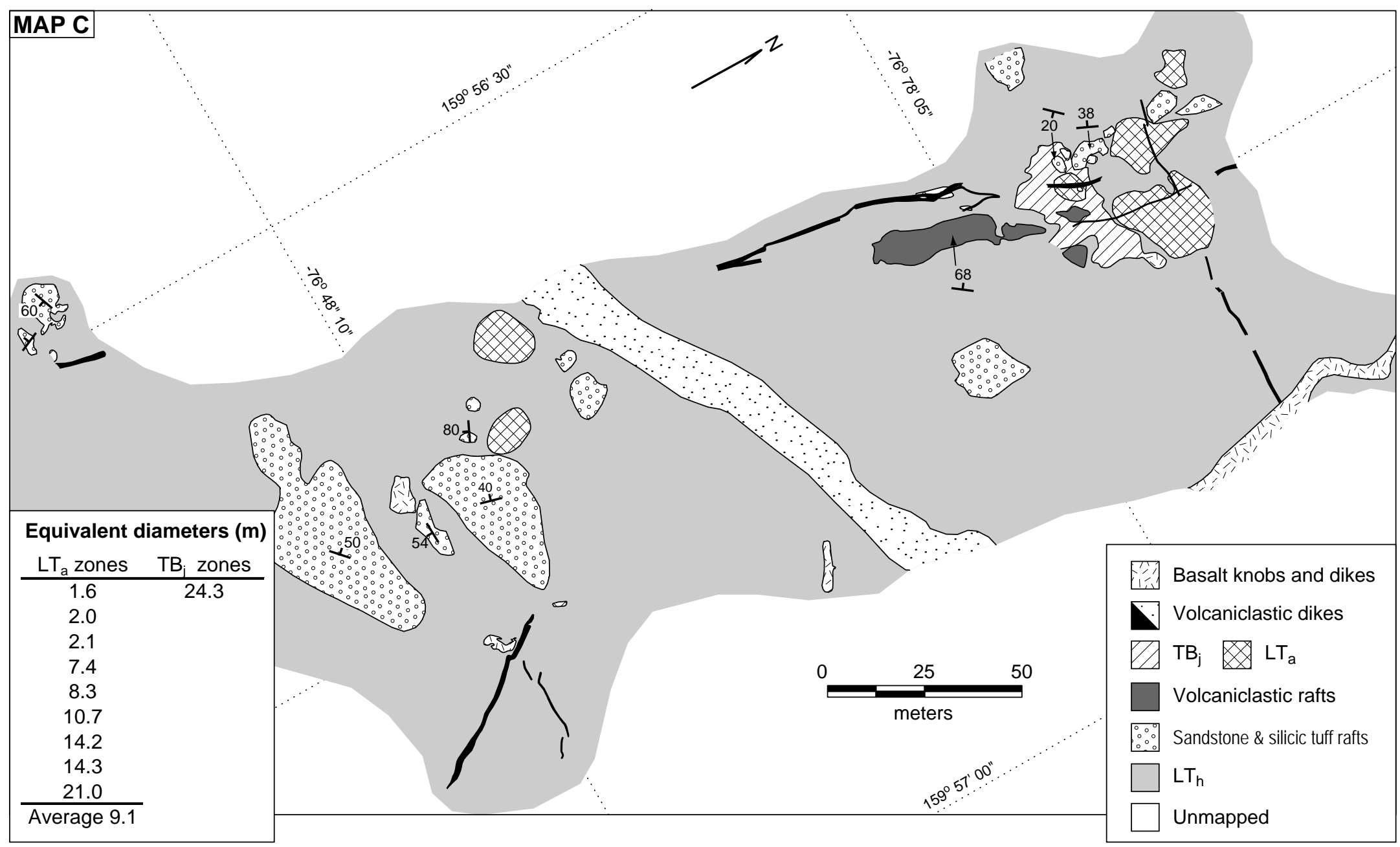

ROSS AND WHITE, COOMBS HILLS, FIG. 4 

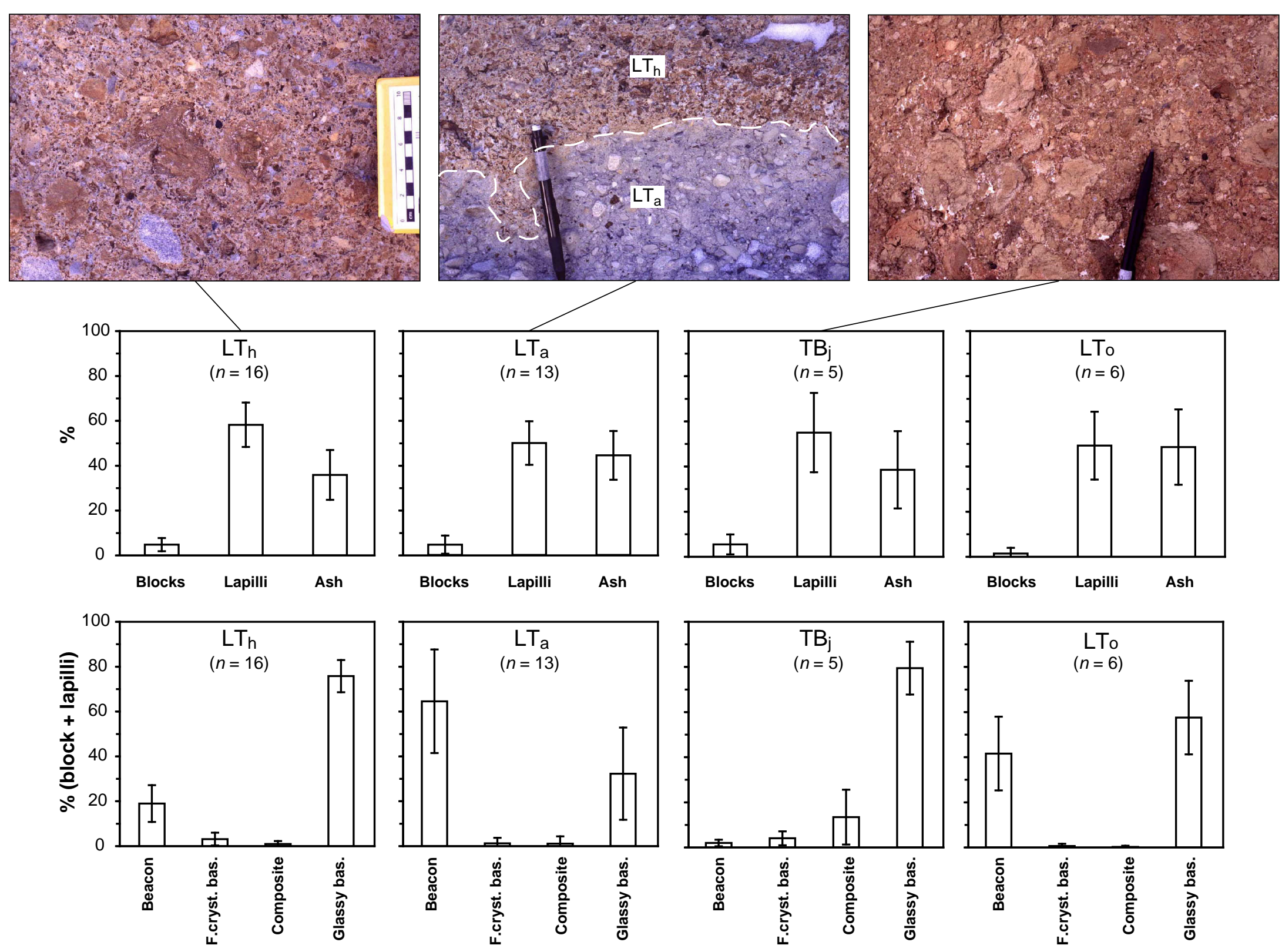

ROSS AND WHITE, COOMBS HILLS, FIG. 5 

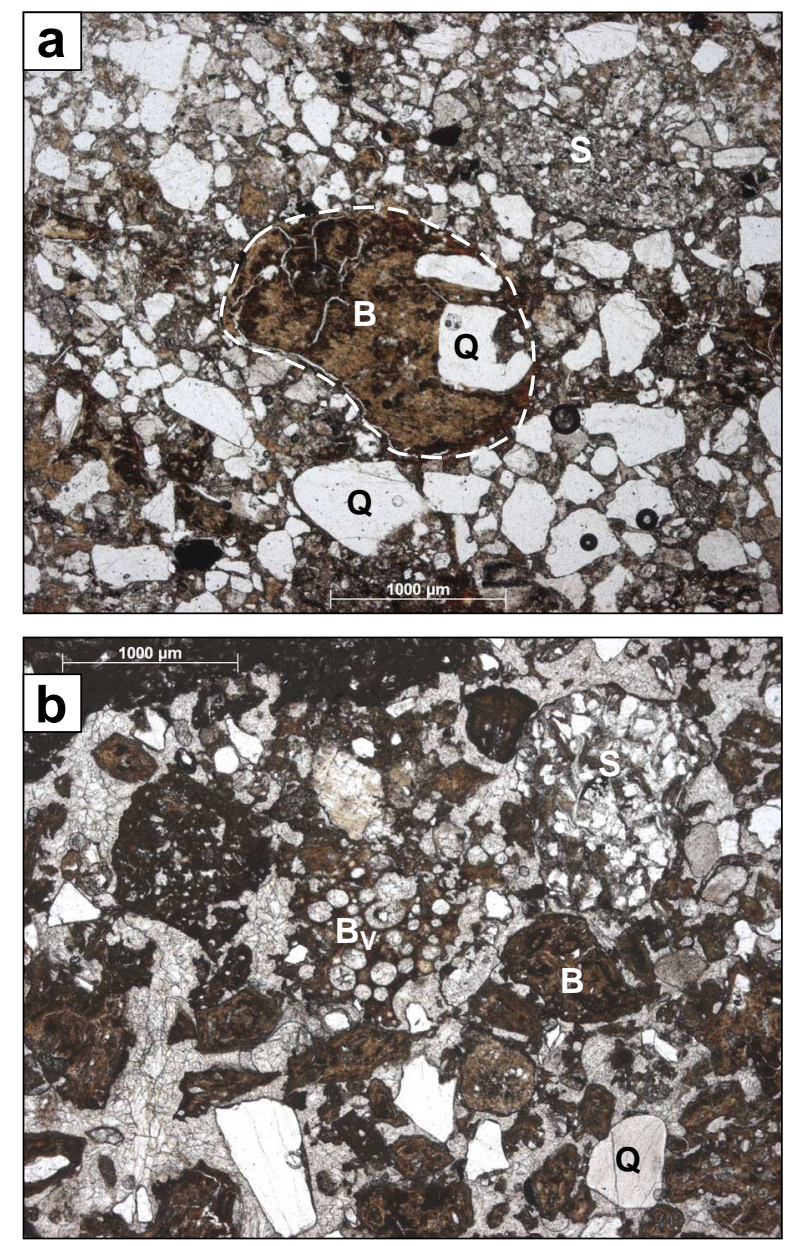

ROSS AND WHITE, COOMBS HILLS, FIG. 6 


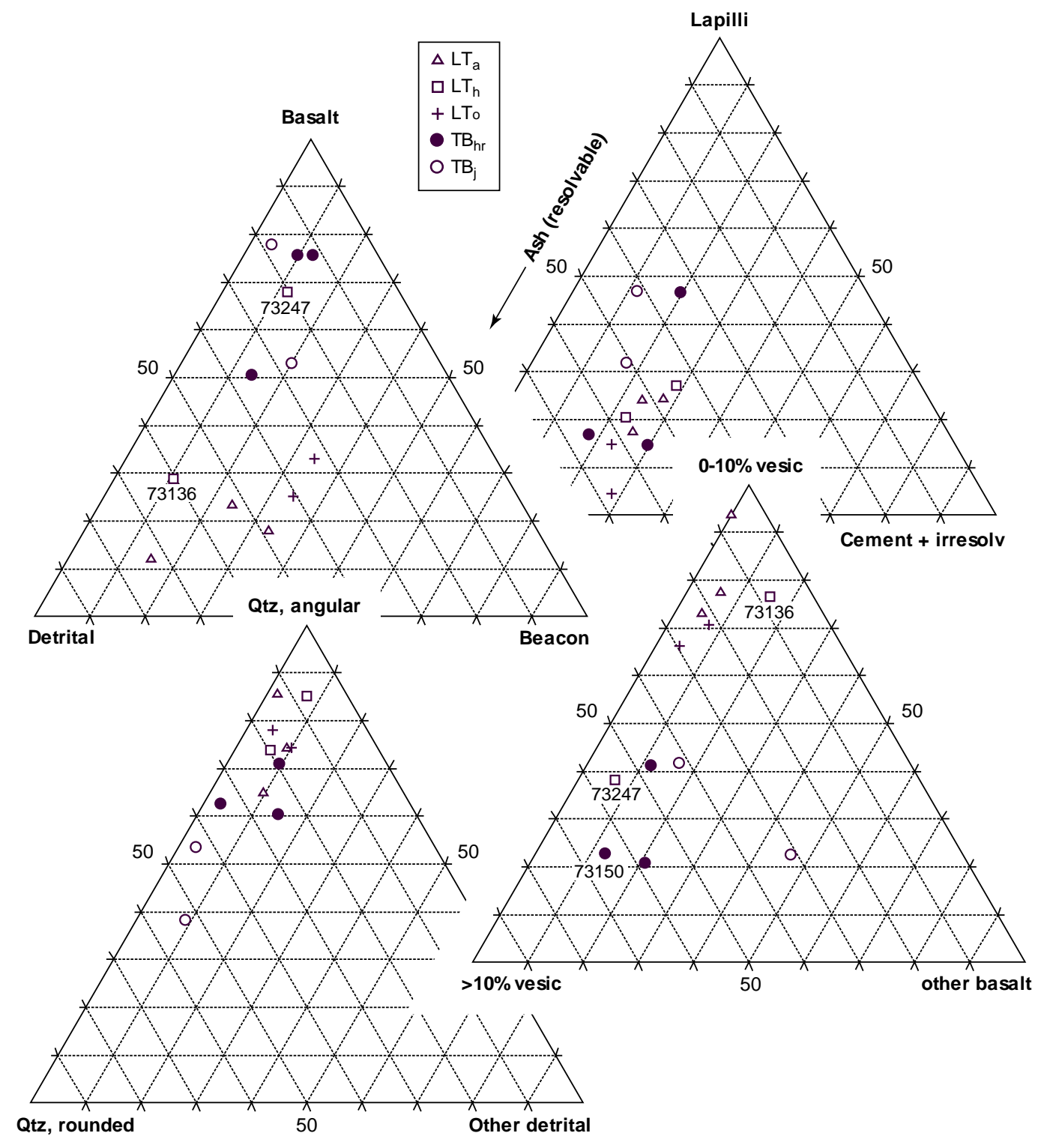

ROSS AND WHITE, COOMBS HILLS, FIG. 7 


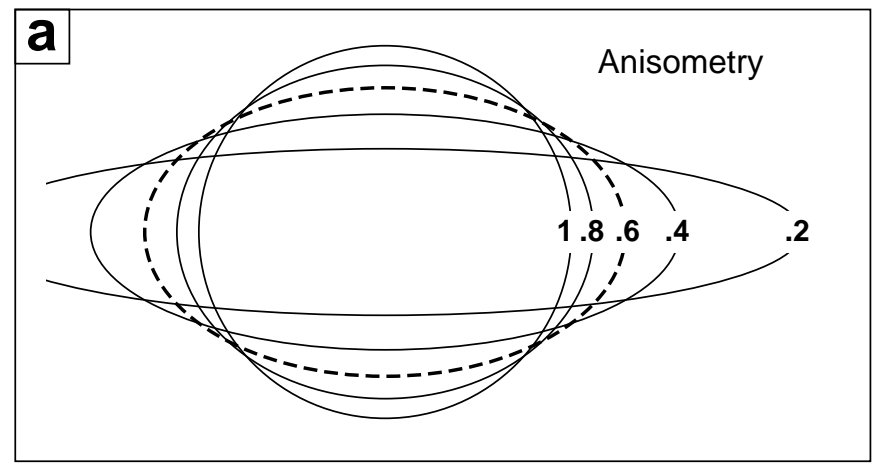

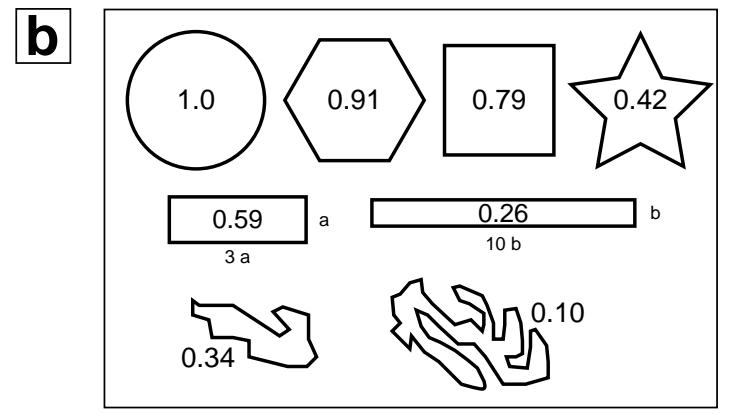

Shape factors

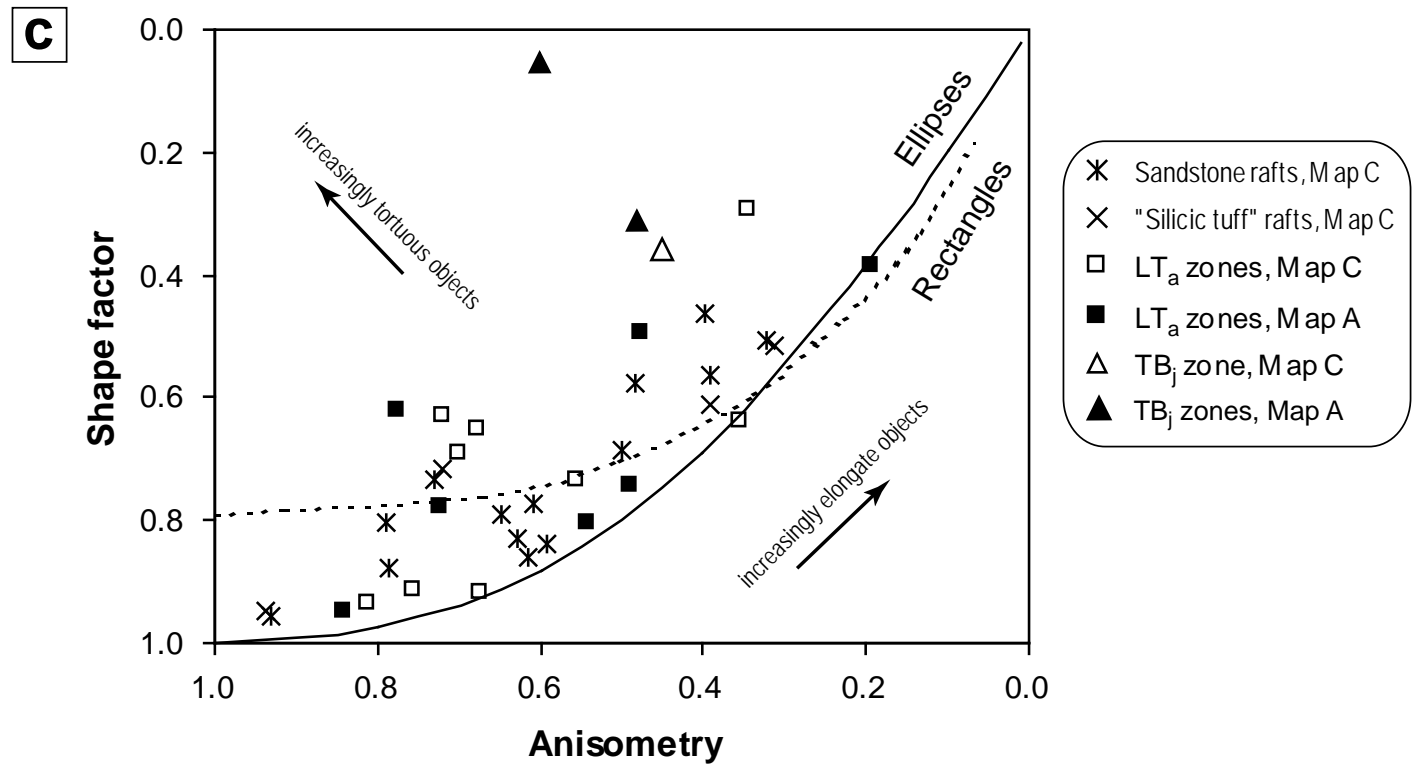

ROSS AND WHITE, COOMBS HILLS, FIG. 8 

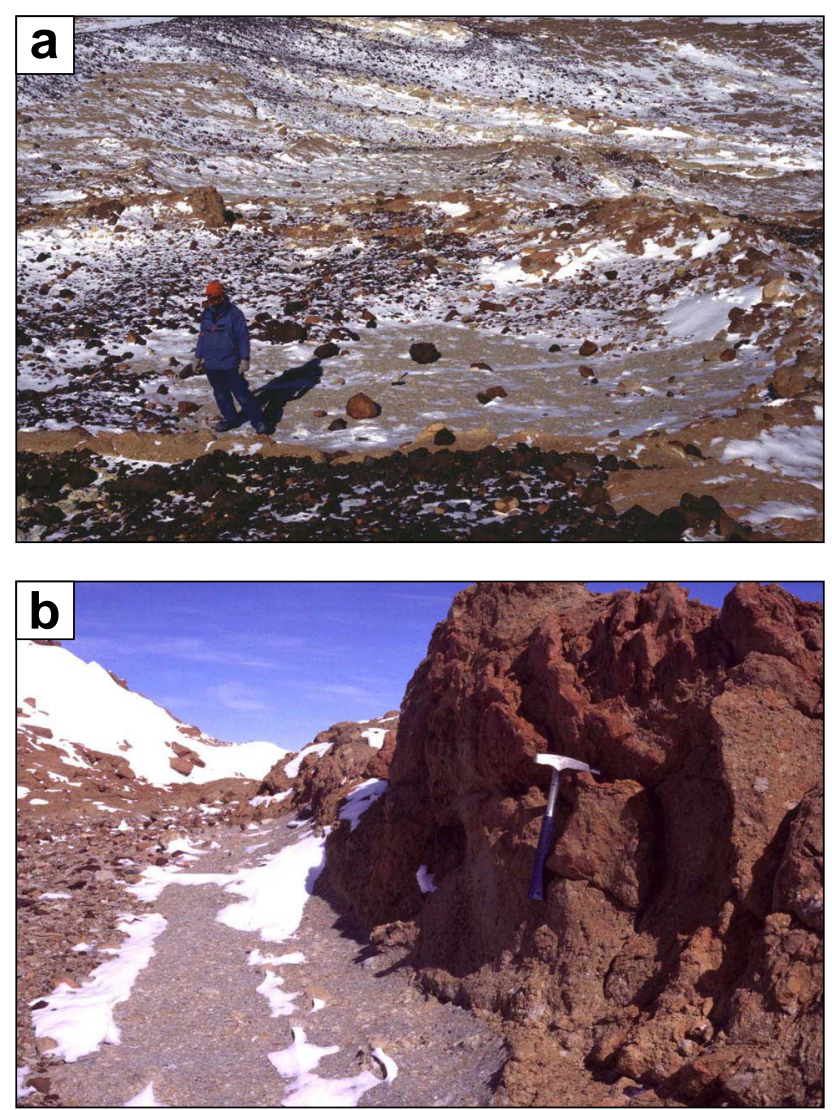

ROSS AND WHITE, COOMBS HILLS, FIG. 9 


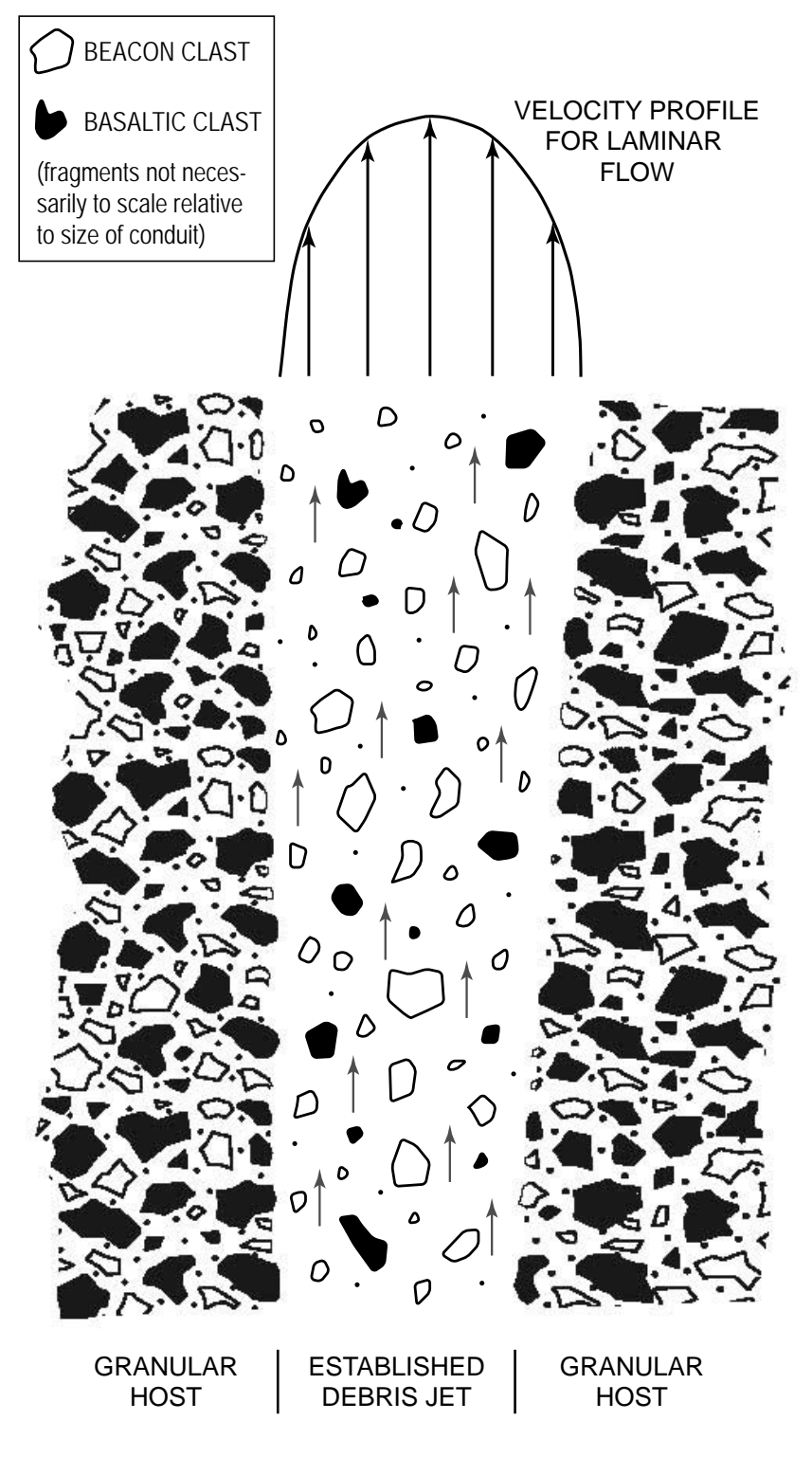

ROSS AND WHITE, COOMBS HILLS, FIG. 10 


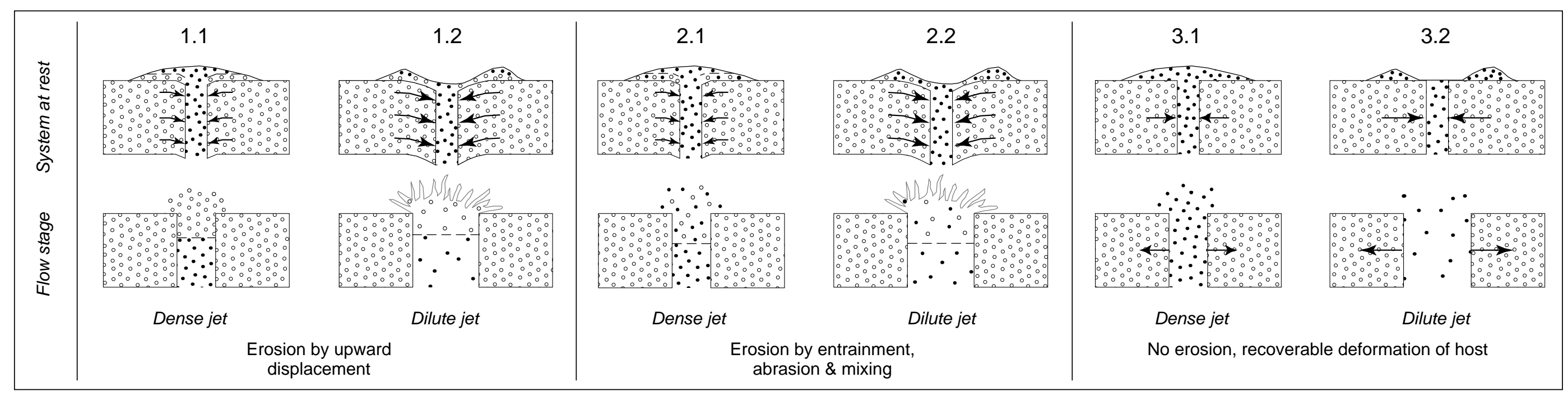

ROSS \& WHITE, COOMBS HILLS, FIG. 11 